
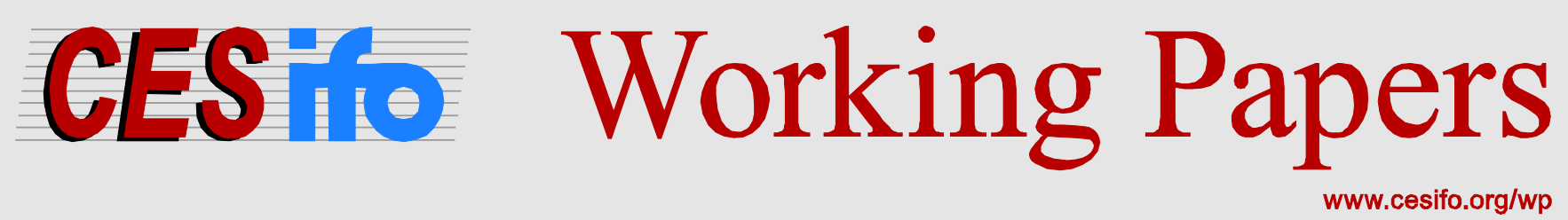

\title{
Designing Fiscal Policy to Address the External Costs of Energy
}

\author{
Ian Parry \\ CESIFO WORKING PAPER NO. 5128 \\ CATEgORY 10: ENERGY AND CLIMATE ECONOMICS \\ DECEMBER 2014
}
An electronic version of the paper may be downloaded
- from the SSRN website: Www.SSRN.com
- from the RePEc website: Www.RePEc.org
- from the CESifo website: www.CESifo-group.org/wp

\section{CESifo}




\title{
Designing Fiscal Policy to Address the External Costs of Energy
}

\begin{abstract}
This paper first reviews the conceptual case for, and appropriate design of, fiscal policies to address major externalities associated with energy use-global warming, local air pollution, and various side effects (e.g., congestion) from motor vehicles. Techniques for (roughly) estimating the magnitude of these externalities, and corrective energy taxes, on a country-bycountry basis are then described. The implications for reforming energy taxes, and the potential environmental, health, and fiscal benefits from reform, are then discussed. A theme of the paper is the critical role of finance ministries in administering tax reforms and ensuring efficient use of revenues.
\end{abstract}

JEL-Code: H230, Q480, Q540, Q580.

Keywords: externalities, energy taxes, getting prices right, air pollution, global warming.

Ian Parry

Fiscal Affairs Department

International Monetary Fund

Iparry@imf.org

December 2014

This paper was prepared for a forthcoming edition of the International Review of Environmental and Resource Economics. 


\section{Introduction}

This paper suggests that fiscal policies-carefully-designed energy taxes or tax-like instruments ${ }^{1}$ - should take center stage in ensuring that energy prices adequately reflect carbon dioxide $\left(\mathrm{CO}_{2}\right)$ emissions, air pollution, road congestion, and other major externalities associated with energy use. Growing alarm about environmental threats, recognition of the limitations of traditional environmental regulations, a preference for revenue-raising instruments following the recent run-up in debt-to-GDP ratios, pressure to reform administered energy prices, and so on, have heightened interest in the potential application of these fiscal policies.

To date, no country has really come close, however, to implementing the ideal fiscal system for mitigating energy externalities. While political economy factors and finance ministries' traditional focus on broader fiscal policy play some role in this, a more basic reason might be that policymakers in different countries have lacked a sense of how to implement the needed reforms - in particular what to tax and by how much — and what would be the resulting environmental, fiscal, and other benefits.

Literature on externality valuation and tax design has however progressed sufficiently that country-specific guidance can now be offered (with appropriate caveats) on these design questions. This essay discusses how this research might be used to formulate policy in developed and developing countries alike.

Some key themes of the discussion include:

- Reforms are a potentially straightforward application of basic tax principles but finance ministry engagement is important. Getting energy prices right most naturally involves a reform and extension to other fuels (or their emissions), of motor fuel excises, which are among the easiest of all taxes to administer. There are complications (e.g., crediting for emissions 'scrubbing', partially transitioning to distance-based vehicle charges over the longer term) but these should be manageable for most countries. What is critical is productive use of revenues, most obviously to lower other taxes (without which the case for green fiscal instruments is seriously undermined).

- Country-specific data (measured in an internationally consistent way) is needed to quantify externalities and efficient tax levels. For instance, the appropriate charge for air pollution damages is sensitive to local emission rates, population density in proximity to emissions sources, the health status of exposed populations, and the local

\footnotetext{
${ }^{1}$ The focus here is principally on taxes rather than their emissions trading analogs.
} 
valuation of health risks, implying overall no clear pattern between efficient air pollution taxes and the level of economic development.

- There is a striking, and pervasive, mismatch between efficient taxation and current practice. For example, environmental externalities warrant substantial excises on coal, yet no country presently taxes coal in an environmentally meaningful way, while most countries undercharge motor fuels, particularly diesel, and are only at base camp in the use of distance-based taxes to alleviate congested roads.

- The fiscal, environmental, and health benefits from getting energy prices right are substantial and reforms can be in countries' national interests. An implication for large $\mathrm{CO}_{2}$ emitters is that carbon pricing need not await global coordination.

- $\quad$ The need for humility. Almost every step in externality valuation could be endlessly debated, data inputs change over time and are often missing, and governments may have their own viewpoints (e.g., over climate damages or the valuation of pollutionhealth risks) - there is no such thing as 'the' correct fuel tax that everybody should agree on. The objective should therefore be to provide a framework for discussing the issues, one that allows for different viewpoints, and provides robust directions for policy reform.

- Other policies are needed, but should not detract from fiscal reforms. Related market failures, infrastructure needs, and so on, warrant a diffuse set of other policies. ${ }^{2}$ However, many of these policies require project-specific data, and the welfare gains from individual policies are likely on smaller scale to those getting energy prices right.

The paper begins by discussing the major externalities from fossil fuel energy, along with the basic case for, and appropriate design of, fiscal instruments to mitigate them, what fiscal policies are currently in place, and obstacles to reform. Section 3 discusses methodologies for valuing externalities and assessing corrective energy taxes. Section 4 discusses what this implies for policy in different countries and the impacts of potential reforms. Section 5 offers some concluding thoughts. ${ }^{3}$

\footnotetext{
${ }^{2}$ Taking just the example of road congestion, complementary measures might include, for example, appropriate pricing of mass transit and parking spaces, staggering work hours for government employees, encouraging biking and walking, improving the design of roads and intersections to improve traffic flows.

${ }^{3}$ The focus here is on drawing out basic practical insights, rather than attempting to summarize the large literature on environmental taxation - much of the discussion follows a recent, in-depth treatment of the issues in Parry et al. (2014). For some broader perspectives see, for example, Bovenberg and Goulder (2002), Eakins and Speck (2011), Fullerton, Leicester and Smith (2008), Metcalf (2009), Newbery (2005), OECD (2010), and Sterner (2002).
} 


\section{Energy Externalities and the Case for, and Design of, Fiscal Policies to Address Them}

While there are numerous potential candidates for externalities associated with extraction, processing, storage, distribution, and use of fossil fuels, in many cases they are relatively small in magnitude, difficult to quantify, or the nature of the externality is unclear (see Box 1). The discussion here is confined to a very limited number of quantitatively important externalities, briefly introduced in Subsection A. The following two subsections get into the rationale for, and conceptual design of, fiscal instruments. Subsection D discusses the implications of related market failures (e.g., from technology spillovers) and subsection E current fiscal policies affecting energy. The last subsection discusses obstacles to reform.

\section{A. Major Externalities}

The focus here is on the following externalities associated with fossil fuel use:

- $\mathrm{CO}_{2}$ emissions, resulting from fossil fuel combustion which (along with other greenhouse gases accumulating in the atmosphere) are projected to raise global temperatures above pre-industrial levels by around $3-4^{\circ} \mathrm{C}$ by 2100 (IPCC 2013), implying serious risks for the stability of the global climate system.

- Outdoor air pollution, also resulting from fossil fuel combustion which (along with other sources like biomass burning) was responsible for an estimated 3.7 million premature deaths a year worldwide in $2012 .{ }^{4}$

- Broader externalities from road vehicles, primarily congestion and accidents. Accidents, for example, result in an estimated 1.2 million annual deaths worldwide (WHO 2014).

\footnotetext{
${ }^{4}$ According to WHO (2014), there were 3.7 million deaths from outdoor air pollution, 4.3 million from indoor air pollution, and 7.0 million in total, given 1 million jointly caused by indoor and outdoor air pollution. The focus here is on outdoor air pollution, where the externality is more clearly defined.
} 


\section{B. The Case for Fiscal Instruments}

There are three basic rationales for using fiscal instruments-taxes on fuels or their emissions, or trading systems with allowance auctions-as the centerpiece of efforts to internalize the above externalities:

- They are the most effective instruments for exploiting the full range of externality mitigation opportunities - so long as they directly target the right base (e.g., emissions).

- They achieve environmental protection at lowest overall cost to the economy-so long as the revenues are used productively (e.g., to lower the burden of other taxes).

- They strike the efficient balance between environmental benefits and economic costs—so long as tax rates are aligned with (marginal) environmental damages.

These points are worth elaborating, given their importance for policy instrument choice and design.

(i) Environmental Effectiveness: The Importance of Targeting the Right Base

An effective environmental policy exploits opportunities for externality mitigation across the board. The example of (energy-related) $\mathrm{CO}_{2}$ mitigation best illustrates the point.

The major (near term) possibilities for reducing energy-related $\mathrm{CO}_{2}$ might, for a country with a diverse fuel mix like the United States, be categorized as follows (see the column headings in Table 1):

- switching from fossil fuel power generation to renewables;

- shifting from coal to natural gas in power generation, and from these fuels to nuclear;

- reducing electricity demand through higher efficiency (for buildings, appliances, etc.)

- reducing electricity demand through less use of electricity-consuming products (e.g., conserving on air conditioning)

- improving the fuel efficiency of vehicles;

- reducing vehicle use; and

- reducing direct use of fuels (e.g. natural gas, home heating oil) by firms and industry.

A tax on the carbon content of fossil fuels promotes all of these responses-indicated by the seven $\sqrt{ }_{\mathrm{s}}$ in the first row of Table 1 -as the tax is passed forward into higher prices for fuels (especially carbon-intensive ones), electricity, and so on. ${ }^{5}$

\footnotetext{
${ }^{5}$ Some of the tax might be passed back in lower supply prices, but a relatively minor fraction, given that fuel supply curves are relatively flat in the longer term and the link between domestic and international prices.
} 
A subsidy for renewable power generation fuels, in contrast, gets only one $\sqrt{ }$. $\mathrm{A} \mathrm{CO}_{2}$ per kilowatt hour (kWh) standard for the power sector would be more effective, as it promotes all responses for lowering the emissions intensity of power generation, and it reduces electricity demand, though by less than that for the carbon tax (since there is no pass through of tax revenues into prices). Efficiency standards for appliances, buildings, and other electricity-using goods promote only the third response, while (moderately) affecting the use of electricity-consuming products in the wrong direction - the 'rebound effect'. Typically however, multiple regulations are implemented and the most promising-combining a $\mathrm{CO}_{2}$ per kWh standard for power generation with efficiency standards for buildings, appliances, vehicles, and so on-would promote four responses in Table 1. But even this combination (and to date policymakers have preferred renewables incentives to $\mathrm{CO}_{2}$ per $\mathrm{kWh}$ standards) misses some opportunities, perversely affects others through rebound effects, complicates administration, and sacrifices cost effectiveness (unless some harmonizing mechanism leads to a single emissions price across all programs).

The effectiveness of indirect environmental taxes is also limited. For example, excises on electricity consumption get two $\sqrt{ }_{\mathrm{s}}$ in Table 1 , as do motor fuel taxes, while taxes on vehicle ownership have just a weak effect on driving (they reduce the vehicle stock but not the intensity of vehicle use). ${ }^{6}$ Yet all of these taxes are common amongst most advanced countries (see below) and are routinely rationalized on environmental grounds.

\section{(ii) Cost Effectiveness: The Importance of the Broader Fiscal Context}

Traditionally, it was thought that the only condition for a cost effective environmental policy is that all sources (causing the same marginal external damage) face the same price on environmental damages. ${ }^{7}$

However, it well established in public finance (e.g., Harberger 1964) that the welfare effect of a policy depends on how it impacts other sources of distortion in the economy (beyond the externality), at least if there is little prospect, for the foreseeable future, of those distortions being removed or corrected. Even across free-market economies like the United States, distortions from market failures and policy interventions are pervasive, so the trick is

\footnotetext{
${ }^{6}$ A simple vehicle ownership tax in the United States would miss about 98 percent of the $\mathrm{CO}_{2}$ reductions that would be exploited under a comprehensive carbon tax (Parry et al. 2014). Increasingly, vehicle taxes have been related to engine size or, more recently, $\mathrm{CO}_{2}$ emission rates per $\mathrm{km}$, based on classifying vehicles into different bins. But even these taxes miss many opportunities to improve fuel efficiency (e.g., incremental technology improvements that do not shift a vehicle into a different tax bin, less erratic driving behavior, faster retirement of older, less efficient vehicles).

${ }^{7}$ See, for example, Baumol and Oates (1971), Dales (1968), Kneese and Bower (1968), Montgomery (1972).
} 
to sort out those that make a real difference for practical policy purposes. This subsection focuses on especially important sources of distortion from the broader fiscal system (beyond the energy sector)—other subsections consider further sources of distortion.

The broader fiscal system-taxes on personal and corporate income, payrolls, and consumption-distort both the scale of economic activity (e.g., though lowering the returns to labor force participation, effort on the job, investments in human and physical capital) and its composition (e.g., by biasing the choice between formal and informal work, between low and high-paying jobs, or between ordinary and tax-preferred spending, like owner-occupied housing and fringe benefits). ${ }^{8}$ Cutting broader taxes therefore helps to alleviate both sources of distortion - the so-called 'revenue recycling effect'. Offsetting this is the 'tax-interaction effect'-the welfare loss as higher energy prices exacerbate tax distortions by contracting the overall level of economic activity through reducing the real returns to factor supply. To a first approximation, higher energy prices may not exacerbate composition distortions however, at least if they have little effect on the relative price of products from tax-preferred versus ordinary sectors (Parry and Bento 2000) or on the relative price of informal versus formal activities (mostly services) in competition with the black market (Bento et al. 2010).

Figure 1 provides some rudimentary sense (based on simple formulas derived in Parry and Williams 2010) of how fiscal interactions can radically alter welfare costs for environmental taxes that reduce an externality (e.g., emissions) by anywhere between 0 and 100 percent. There are two key broader fiscal parameters underlying these calculations, the efficiency cost from the last dollar of revenue raised through broader taxes, taken here to be 30 cents, and the relative contribution of the scale and composition effects to this cost- the black curves in Figure 1 indicate cases where 60 percent of the efficiency gain comes from the scale effect (40 percent from the composition effect), and the green and blue cases where 80 and 40 percent respectively of the efficiency gain comes from the scale effect (a guesstimate of a plausible range across countries).

The key point from this figure, and related literature ${ }^{9}$, is the critical importance of efficient revenue use. With recycling, using the black curves, and taking the example of a 30 percent reduction in the externality, welfare costs are about 30 percent lower than the partial equilibrium costs (the Harberger triangle under the marginal abatement cost curve), but are over 200 percent higher than partial equilibrium welfare costs when revenues are not used to

\footnotetext{
${ }^{8}$ Empirical work in public finance over the last 20 years has underscored the critical importance of capturing both the scale and composition effects (my terminology) when measuring the efficiency costs of the tax system (e.g., Feldstein 1995, 1999, Gruber and Saez 2002, Saez et al. 2012) and this is now the standard treatment in public finance texts. The approach involves measuring how the tax base responds to changes in tax rates, as this captures all behavioral responses to the tax (not just changes in factor supply).

${ }^{9}$ See, for example, Fullerton and Metcalf (2001), Goulder et al. (1999), Parry et al. (1999).
} 
increase economic efficiency. The latter result reflects the large size of the tax-interaction effect relative to the partial equilibrium welfare cost, while the former reflects the revenuerecycling effect dominating the tax-interaction effect—-the so-called 'double dividend'.$^{10}$ And more generally, without revenue recycling Pigouvian taxation can reduce rather than increase welfare (e.g., Parry et al. 1999) and can be more costly than broad-based regulatory approaches (e.g., Goulder et al. 1999) that (because they do not involve the pass through of tax revenues) cause weaker impacts on energy prices and weaker tax-interaction effects.

Two caveats on this. First is that the relative discrepancy between environmental taxes with and without revenue recycling declines sharply at higher mitigation levels, due to shrinkage of the tax base-this is potentially a relevant point for corrective taxes on $\mathrm{SO}_{2}$ emissions in countries with high damages per ton of $\mathrm{SO}_{2}$ (as this incentivizes widespread adoption of clean up-technologies which can dramatically cut emissions) but not congestion fees (where only modest reductions in traffic volumes can substantially alleviate clogged roads). Second is that the welfare costs of environmental taxes cannot be pinned down accurately for (most) countries lacking empirical evidence on the scale and composition effects, though this should not detract from the practical importance of efficient recycling (e.g., avoiding unproductive earmarks) when substantial revenues are at stake. ${ }^{11}$ Third,

\section{(iii) Balancing Benefits and Costs: Was Pigou Right After All?}

According to the traditional partial equilibrium model of corrective taxation, the tax level that maximizes environmental benefits net of mitigation costs equals (marginal) environmental damages. Clearly, environmental damages are uncertain, but imposing a charge equal to a best assessment of environmental damages yields potentially much higher welfare gains compared with the zero welfare gains from no tax at all, and divergences in welfare from policy errors may not be that substantial. ${ }^{12}$ Are there any reasons for setting taxes differently from estimated environmental damages?

As just discussed revenue-neutral environmental taxes may (over some range) generate a net welfare gain (at the margin) from interactions with the broader fiscal system.

\footnotetext{
${ }^{10}$ See Parry and Bento (2000) and Bento et al. (2010). Some early models (e.g., Bovenberg and Goulder 1996) suggested that the revenue-recycling effect falls short of the tax-interaction effect, even for small emissions reductions. However these papers capture just the scale effect of broader taxes (as they were written before the empirical importance of the composition effect was recognized) and therefore significantly understate the welfare gains from recycling.

${ }^{11}$ A further problem with earmarking is that there has been a tendency to set tax levels to meet revenue needs, which may imply rates well below levels needed to correct for externalities (e.g., Opschoor and Vos 1989).

${ }^{12}$ For example, setting an environmental tax 50 percent below, or 50 percent above, the true corrective level still achieves about 75 percent of the potential welfare gains.
} 
This does not (in my view) constitute a practical case for setting environmental taxes in excess of corrective levels however, given uncertainty over the fiscal parameters needed for this adjustment, that the mark-up declines (eventually becoming negative) with the level of mitigation, and not least the difficulty of conveying all this to policymakers. While a fiscal rationale might be made for product taxes when broader taxes cause significant distortion due to the composition effect, these taxes should apply to relatively inelastic bases (e.g., vehicle sales and electricity consumption rather than fuels and emissions). ${ }^{13}$

Another possible reason to set environmental taxes in excess of Pigouvian levels is to counteract price/marginal cost wedges in product markets (e.g., due to monopoly power). But this argument is highly case specific rather than general, and for the United States at least, calculations by Oates and Strassmann (1984) suggest any markups are not that large in empirical terms. The argument that environmental taxes should be set well above Pigouvian levels to promote clean technology innovation is also debatable (see below), not least because other instruments can more directly target technologies where spillovers are most severe.

One case however, where the efficient environmental tax may significantly exceed the Pigouvian level, is carbon pricing. This hinges on a second-best argument - that there are large national co-benefits from carbon taxes (reduced air pollution deaths, congestion and accident externality benefits, net of fuel taxes, from reduced vehicle use) that will not be internalized through other measures in the medium term. Parry, Veung and Heine (2014) estimate (using data discussed below) that co-benefits warrant $\mathrm{CO}_{2}$ taxes averaging $\$ 57.5$ per ton across the top-twenty $\mathrm{CO}_{2}$-emitting countries, before any charge is levied for climate damages (see also Nemet et al. 2010). A related point is that co-benefits vary considerably across countries (less than \$15 per ton in Australia, Brazil, Italy, and South Africa, over \$60 per ton in China, Iran, Korea, Indonesia, Poland, Russia, and Saudi Arabia), implying that efficiency in this regard requires differentiated, rather than uniform, $\mathrm{CO}_{2}$ prices across countries.

\footnotetext{
${ }^{13}$ If broader taxes distort only factor markets then the analysis of Diamond and Mirrlees (1971) applies, and product taxes only have a role under special circumstances (e.g., if the products are relatively weak substitutes for leisure). However, some taxation of products with inelastic bases can be efficient on fiscal grounds when broader taxes cause significant distortion to the composition of economic activity. A further point is the importance, in countries with value added tax (VAT) systems, of fully covering fuels that are used as inputs in the informal sector, as this provides incentives for entities to register in the formal sector (to receive VAT refunds), thereby reducing distortions from black market activities.
} 
But leaving aside the last issue, following the Pigouvian rule appears for the most part to be an appropriate practical guide. Furthermore, it seems reasonable to measure the Pigouvian tax using marginal damages estimated at current tax levels. ${ }^{14}$

\section{Further Design Issues for Fiscal Instruments}

This subsection quickly summarizes the bases that should be targeted by fiscal policies to correct the above externalities, administrative options for these instruments, and the choice among pricing instruments.

(i) Defining the Tax Base: One Charge for Each Externality

Conceptually the efficient tax system is straightforward and should comprise the following three components:

- A carbon charge on the supply of each fossil fuel, equal to the fuel's $\mathrm{CO}_{2}$ emissions factor times the environmental damage per ton of $\mathrm{CO}_{2}$. Alternatively, charges can be levied downstream on $\mathrm{CO}_{2}$ emissions from large stationary sources, combined with upstream charges to cover mobile and (most) small-scale emissions sources. ${ }^{15}$

- An air pollution charge on each fossil fuel, equal to the sum of emissions factors for direct $\mathrm{PM}_{2.5}, \mathrm{SO}_{2}$ and $\mathrm{NO}_{\mathrm{x}}$, where each is weighted by the respective environmental damages per ton, and there is appropriate crediting for emissions capture (e.g., $\mathrm{SO}_{2}$ scrubbers). Alternatively, again for large stationary emitters, smokestack emissions can be charged directly.

- Additional charges on motor fuels, for the interim, to reflect congestion, accident, and road damage externalities, though transitioning to mileage-based taxes (varying with road class and time of day) to more effectively reduce congestion, in particular, which should be feasible for many countries over the longer term. ${ }^{16}$

\footnotetext{
${ }^{14}$ For global warming, this is because damages depend on the accumulated stock of greenhouse gases in the atmosphere and one country's emissions in one year add a negligible amount to this stock (Pizer 2002). For air pollution, the relation between fatalities and pollution concentrations appears to be approximately linear, at least in the relevant range for corrective taxes (see below).

${ }^{15}$ For some discussion of alternative approaches in the context of trading systems see, for example, Stavins (2007).

${ }^{16}$ Congestion taxes can be implemented in a bottom-up fashion with local authorities introducing charges in their jurisdiction (as in current schemes, for example, in Milan, London, and Stockholm), or in a top-down fashion by national governments, perhaps using Global Position Monitoring Systems to track vehicle's travel movements. The latter have been proposed in the United Kingdom and the Netherlands for passenger vehicles, and introduced for trucks, for example, in Germany. For some discussion of congestion pricing design, and
}

(continued) 
The (interim) motor fuel tax component is the most questionable on conceptual grounds, given that fuel taxes are such a blunt instrument for alleviating congestion (high fuel taxes in the United Kingdom, for example, are not effective in alleviating heavy congestion in London) and other policies are needed (e.g., road safety upgrades to reduce accidents). However, so long as fuel taxes remain the only fiscal instrument, it is entirely appropriate to reflect all externalities in setting their rates-not doing so can forego significant welfare gains.

In computing corrective motor fuel taxes it is important to consider what portion of the tax-induced (long-run) fuel reduction comes from behavioral responses that mitigate each particular externality-most importantly, congestion and accident benefits need to be multiplied by the fraction of the fuel reduction that comes from fewer vehicle miles travelled (to the extent fuel reductions come from increases in average fuel efficiency there are no direct congestion and accident benefits).

\section{(ii) Administrative Considerations: Taxing Fuels vs. Emissions}

We leave aside the administration of mileage-based taxes here, and focus on the more immediate issue of whether to levy pollution charges on fuel or emissions. Traditional environmental policies (implemented by environmental agencies) have tended to focus on the latter, but from a finance ministry's perspective, the former seems more natural. In particular, a carbon tax levied on fossil fuels would represent a straightforward extension of motor fuel excises (building into them a carbon charge and applying similar charges to the supply of other petroleum products, coal, and natural gas) which are well established in many countries and are among the easiest of all taxes to administer, given the small number of taxpayers (a US carbon tax, for example, would require monitoring around 1,500-2,000 companies-see Metcalf and Weisbach 2009, Calder 2014). ${ }^{17}$

Upfront charges on fuel use for air emissions may also have attractions for some countries. They could be collected simultaneously with carbon charges, therefore simplifying

experience to date, see Arnott, Rave, and Schöb (2005), Lindsay (2006, 2007), Santos (2004), Small and Verhoef (2007), and TRB (2006).

${ }^{17}$ In principle, the charge would also cover fuels used in international aviation and maritime transport, which are a significant and growing source of global $\mathrm{CO}_{2}$ emissions - in fact these fuels are effectively subsidized at present due to favorable treatment from the broader fiscal system, reinforcing (in a second-best way) the efficiency case for fuel charges. The problem here is the international mobility of the tax base (especially for maritime, where ships can easily divert to ports where fuel charges are not applied), requiring some degree of international coordination along with compensation schemes for low-income countries, though the practicalities should be manageable (e.g., Keen, Parry, and Strand. 2013). 
administration (rather than having distinct programs for each air pollutant and carbon). And putting the onus on firms to demonstrate valid emissions reductions to obtain credits (e.g., for scrubbing emissions), eases the burden on (frequently overstretched) administrative capacity (compared with when officials have to continuously monitor all emission sources). ${ }^{18}$

\section{(iii) Taxes versus Trading: In Principle Equivalent, but in Practice...}

The choice between emissions taxes and emissions trading systems has been discussed numerous times. ${ }^{19}$ The bottom line, in principle, is that either instrument is fine, so long as it is designed right-covering all emissions (effectiveness), exploiting the fiscal dividend (cost effectiveness), and aligning the emissions price with environmental damages on a continual basis (balancing benefits and costs).

In practice achieving these design features seems a bit more convoluted under trading systems. These systems so far have had a downstream focus which excludes small-scale emitters, while a system of fuel taxes would comprehensively cover energy-related emissions. More importantly, trading systems tend to be administered by environmental agencies, which could increase the risk that fiscal opportunities are not fully exploited (e.g., because of free allowance allocation or earmarking of allowance auction revenues). And trading systems need to be accompanied by price stability provisions to maximize net benefits (e.g., Pizer 2002)—most obviously tight price collars aligned to environmental damage (which obviates the need for much trading). Of course environmental taxes emerging from protracted legislative processes could also have design flaws - the details matter a lot and these are difficult to predict in advance.

\section{Related Market Failures: Implications for Policy Design}

This subsection briefly focuses on two potential market failures-technology spillovers and misperceptions over energy efficiency-that are routinely debated in the context of climate and energy policy.

(i) Clean Technology Innovation: Important but Tangential to Tax Design?

Getting energy prices right will provide across-the-board incentives for the development and deployment of cleaner technologies. But investments in specific

\footnotetext{
${ }^{18}$ The discussion here sidesteps the thorny issue (that might be addressed through supplementary pricing schemes) of spatial variation in pollution damages within (large) countries, though Muller and Mendelsohn (2009) estimate only a relatively modest welfare gain from differentiated air pollution charges for the United States over uniform (nationwide) emissions prices.

${ }^{19}$ See, for example, Hepburn (2006), Nordhaus (2007).
} 
technologies-particularly those with high upfront investment costs and long range emissions reductions - may still be insufficient because of technology spillovers, and perhaps also uncertainties over the government's long-term commitment to emissions pricing.

Enhancing incentives for these technologies may yield sizable additional welfare gains, though likely on smaller scale to those from corrective emissions pricing. ${ }^{20}$ And given that barriers vary in severity across different technologies, a portfolio of targeted incentives (at basic research, applied R\&D, and technology deployment), along with emissions pricing, is more efficient than simply raising environmental taxes in excess of environmental damages, which would encourage all technologies (Fischer and Newell 2008). Practical guidelines need to be refined at the country level however, in terms of which instruments (e.g., strengthened patent protection, technology prizes, subsidies etc. to promote R\&D, or standards, feebates, technology subsidies, etc. to promote deployment) should be used, their stringency, and their phase out as clean technologies mature or turn out to be more costly than anticipated.

(ii) Misperceptions over Energy Efficiency Benefits: Economists and Engineers Far Apart

Engineers and economists are still far apart on the question of whether there are large net benefits (leaving aside environmental benefits) from policies to increase energy efficiency. McKinsey \& Company (2014) detail a wide range of available technologies across countries for which the discounted savings in energy costs appear to comfortably exceed upfront investment costs, but that are not currently adopted, perhaps because of some 'misperceptions' over the net benefits. On the other hand, some (though not all) recent economic analyses suggest consumers and firms are in fact making efficient choices, implying the engineering studies might be missing something (e.g., hidden costs such as the inferior quality of fluorescent lighting compared with incandescent).21 The practical questions here are whether supplementary polices are needed and whether there are implications for corrective taxes, for transportation and electricity.

As regards transportation, the first question is not clear cut, even with a large misperceptions market failure. Combining fuel taxes with fuel efficiency incentives, rather than using fuel taxes only, implies that, for a given overall reduction in fuel use, more of it will come from improved fuel efficiency and less from reduced vehicle mileage. This is welfare improving only so long as the efficiency benefits from better targeting the

\footnotetext{
${ }^{20}$ See, for example, Fischer and Newell (2008), Nordhaus (2002), Parry, Pizer, and Fischer (2003), Pizer and Popp (2008). An important caveat here is that there are costs to delaying clean technology transitions-costs that grow over time if economies become more locked into emissions intensive capital and infrastructure (e.g., Acemoglu, et al., 2012).
} 
misperceptions market failure exceed the efficiency losses from doing less to reduce congestion and other mileage-related externalities, which is far from clear (e.g., Parry, Evans, and Oates 20104). A large misperceptions failure could however warrant significantly higher fuel taxes, though this is not considered below, given the contentious nature of the market failure.

And as regards efficiency improvements to electricity-using capital (household appliances, buildings, industrial equipment, etc.), the base of appropriate policies to address the misperceptions market failure (electricity) is distinct from the appropriate base for policies to address externalities (e.g., emissions). Even so, the welfare gains from efficiency policies over electricity taxes may not be that large, unless the former can be comprehensively applied across the range of electricity-using equipment used by households and firms, and even in that case a pricing instrument (feebates, standards with price collars) is the more natural way of ensuring the stringency of the policy is in line with the size of the market failure. ${ }^{22}$

\section{E. Fiscal Policies Currently Affecting Energy}

Many countries already raise a substantial amount of revenue from energy taxes. As indicated in Figure 2, revenues from energy-related taxes averaged 7 percent of total tax revenues among OECD (i.e., developed or advanced) countries in 2010, though the variation was considerable-3 percent in the United States, 15 percent in Turkey (and negative in Mexico, though energy subsides there have since been scaled back following price liberalization). This revenue principally comes from three main taxes-on motor fuels, electricity consumption (mostly residential), and vehicle ownership.

As discussed above, motor fuel taxes are a reasonable interim measure for reflecting the full range of vehicle externalities. The main issue for now-at least until countries start transitioning to a mix of fuel and mileage-based taxes-is whether existing fuel excises are in the right ballpark. Taxes on electricity consumption and vehicle ownership however are poorly targeted from an environmental perspective (though, as noted above, they may have some merit on fiscal grounds).

Rather than tax fossil fuel energy, many countries subsidize it substantially. It is estimated that direct fossil fuel subsidies worldwide totaled $\$ 490$ billion in 2011 (see Figure

\footnotetext{
${ }^{21}$ See, for example, Alcott (2014), Alcott and Greenstone (2012), Busse, Knittel, and Zettelmeyer (2013), Helfand and Wolverton (2011), Sallee (2014), and Sallee, West, and Fan (2009).

${ }^{22}$ The latter boils down to the user price of energy, times the fraction of discounted lifetime energy savings that are not internalized (Parry, Evans, and Oates, 2014).
} 
3(a)). Mostly these reflect consumption subsidies, stemming from the failure to fully reflect international fuel prices in retail prices (e.g., due to administered pricing at state-owned fuel suppliers), though they also include production subsidies (e.g., tax relief for exploration and development).

Petroleum accounted for 44 percent of these subsidies, but coal (the most carbonintensive fuel) only 1 percent, so eliminating these subsidies would have only limited impacts on reducing global $\mathrm{CO}_{2}$ emissions. In addition, Middle East and North African countries (dominant conventional oil producers) accounted for almost half of the subsidies and advanced countries only 5 percent.

However, this picture looks radically different under a broader notion of energy subsidies, one that (crudely) takes into account implicit subsidies from the failure to charge for environmental damages (see Figure 3(b)). ${ }^{23}$ For one thing, total subsidies are now four times as large at $\$ 2$ trillion, suggesting that pricing for externalities is far more important than scaling back direct subsidies. Furthermore, coal now accounts for a substantial share (36 percent) of the subsidy, reflecting the failure to charge for its high carbon and local pollution emissions. And advanced countries are now responsible for a large share (32 percent) of the subsidy, underscoring that energy price reform is a pressing issue not only for developing countries, but also developed countries. ${ }^{24}$

\section{F. Moving Ahead with Energy Price Reform: "It Always Seems Impossible until it Gets Done” ${ }^{25}$}

While the rest of the paper seeks to provide quantitative specifics on where, ideally, different countries should be headed in terms of energy price reform, this subsection focuses on getting it done in practice. This is the hard part-frequently energy price reforms are fiercely resisted. ${ }^{26}$ Sound economic analysis, nonetheless, can still be a critical ingredient of the reform process.

\footnotetext{
${ }^{23}$ This seems the most appropriate definition from an efficiency perspective, as it is the difference between existing and efficient fuel prices that matters, not the share of this difference that reflects direct subsidies versus environmental damage.

${ }^{24}$ In contrast, the call to phase out energy subsidies at the 2009 G20 meeting in Pittsburg was viewed as a message from developed to developing countries.

${ }^{25}$ Quote from Nelson Mandela.

${ }^{26}$ They can be a major issue in election campaigns. For example, Tony Abbott's pledge to repeal the emissions trading program was a major issue in the last Australian election, as was Tony Blair's pledge to restore reduced value added tax rates on household fuels in the 1997 UK election.
} 
For one thing, policymakers need to communicate to the public the benefits from energy policy reform, which requires quantification of, for example, potential $\mathrm{CO}_{2}$ reductions, pollution deaths avoided, and revenues (and, importantly, how they will be returned to the public). For another, objective information is needed on how the impacts of reforms are distributed across different households and firms, to discipline contentious debates over who gains and who loses, and to inform the design of possible compensating measures for vulnerable or politically influential groups. ${ }^{27}$ Household and firm incidence along with respective compensation instruments, are briefly discussed in turn.

\section{(i) Household Incidence}

For developed countries, there is often a concave relation between budget shares for certain energy products (especially electricity, less so for transportation and heating fuelsOECD 2014) and annual household income, so higher energy prices are regressive. For example, the loss in consumer surplus relative to annual income from a US carbon tax (prior to recycling) is about four times larger for the bottom income decile as for the top income decile (e.g., Mathur and Morris 2014). But this finding likely overstates, perhaps substantially, the regressivity of energy taxes.

For one thing, annual consumption expenditure is often regarded as a better measure of household wellbeing than annual income, and disparities in consumption income across households are far less pronounced than disparities in income (e.g., Hassett et al. 2009). For another, the focus should be on the distributional incidence of the whole policy package. In particular, recycling of environmental tax revenues can affect, quite dramatically, the overall incidence of energy tax reform, and there are many permutations of broader tax/benefit adjustments that might accompany environmental tax reform. For example, if some revenues are used to cut payroll and consumption taxes, increase personal income tax thresholds and subsidies/tax credits for low-paid jobs, or strengthen social safety nets, this will make the overall policy more progressive. The bottom line is that distributional concerns at the household level should not hold up energy tax reforms, because there are far more efficient instruments for achieving distributional objectives than holding down energy prices below levels warranted by supply costs and environmental damages. ${ }^{28}$

\section{(ii) Burdens on Firms}

\footnotetext{
${ }^{27}$ Other ingredients for successful reform might include some common sense principles, like sequencing reforms and de-politicizing energy price setting (Clements et al. 2013), along with a favorable political environment.

${ }^{28}$ For example, only around 3-7 percent of the benefits from gasoline and diesel subsidies accrue to the bottom income quintile in petroleum producing countries (Clements et al. 2013).
} 
Higher energy costs for energy-intensive, trade-exposed industries (e.g., steel, aluminum, cement producers) are also a concern due to competitiveness impacts and emissions leakage. But leakage effects may not be that substantial ${ }^{29}$ and efficient resource allocation implies that firms should eventually go out of business if they cannot compete when domestic energy is appropriately priced (though worker re-training and re-location programs can ease the transition). Fischer, Morgenstern, and Richardson (2013) discuss various (ideally transitory) options for compensating vulnerable firms (e.g., corporate tax cuts, production subsidies, border tax adjustments, exemptions through rebates for energy costs), though all of them have drawbacks.

\section{Quantifying Externalities}

This section discusses techniques for measuring the externalities listed in Section 2A, going into some detail, given the importance of establishing defendable estimates of corrective energy taxes. The focus is on air pollution and broader vehicle externalities, as the external costs of $\mathrm{CO}_{2}$ emissions, though disputed, have received considerable attention elsewhere (e.g., US IAWG 2012, Nordhaus 2014) and do not vary across countries. ${ }^{30}$

Many parameters underlying environmental damages are uncertain and contentious, and different governments may have their own views (e.g., for the valuation of mortality risk or travel time). However, providing a framework where the parameters underlying corrective fuel taxes are transparent, along with an explanation of how plausible starting values for parameters might be assessed for different countries, is especially valuable. It helps to frame dialogue over policy reform and disciplines that debate by clarifying the implications of alternative viewpoints; it sheds light on the factors that cause corrective taxes to differ across fuel products and countries; and it provides a benchmark against which other instruments and policy designs can and should be evaluated to better illuminate the tradeoffs.

\footnotetext{
${ }^{29}$ For example, Böhringer, Carbone, and Rutherford (2012) estimate that leakage offsets around 5 to 20 percent of the emissions reductions from carbon pricing, depending on the size of the coalition of countries taking action. This leakage reflects not only the international migration of economic activity, but also increases in fossil fuel use in other countries as world fuel prices fall in response to reduced demand in countries with carbon pricing. The latter type of leakage (often the most important) is not easily addressed through policy.

${ }^{30}$ Corrective fuel taxes for carbon damages also depend on $\mathrm{CO}_{2}$ emissions factors for different fuels. However these factors are well established and, although they vary substantially across fuel products, there is little variation across countries.
} 


\section{A. Local Air Pollution}

Although air pollution causes a wide range of damages (e.g., building corrosion, crop and ecosystem damage, impaired visibility, non-fatal human illness), the focus here is on mortality impacts, as studies suggest these are, by far and away, the dominant source of damage. ${ }^{31}$

Air pollution damages from coal plants-where emissions are released from tall smokestacks-are discussed first, followed by other stationary sources and ground-level emissions. Emissions from tall smokestacks are the most difficult to deal with, as they can be transported great distances from the emissions source. The key pollutant is fine particulates that are small enough to penetrate the bloodstream and lodge in the lungs, that is, particulate matter with diameter up to 2.5 microns $\left(\mathrm{PM}_{2.5}\right)$, which is formed directly during fuel combustion, and also indirectly as a result of atmospheric reactions involving sulfur dioxide $\left(\mathrm{SO}_{2}\right)$ and (to a lesser extent because it is less reactive) nitrogen oxide $\left(\mathrm{NO}_{\mathrm{x}}\right)$. Ozone also causes health effects, but on a smaller scale to those from particulates, and is ignored here.

\section{(i) Stationary Sources: Coal Plants}

The most common approach for quantifying air pollution damages (see e.g., Muller and Mendelsohn 2012 for an application to the United States) involves the use of:

- air quality models to track how emissions from a particular source affect ambient pollution concentrations in different regions;

- spatial population data to assess the number of people exposed to the pollution;

- health data to assess baseline mortality rates for affected populations and the sensitivity of mortality rates to pollution exposure; and

- value of life (VSL) estimates to convert health impacts into monetary damages.

Most studies stop there but a final step, if the purpose is to assess a set of fuel taxes to internalize air pollution externalities, is to express damages per unit of fuel use, based on the fuel's emissions factors.

Clearly an advantage of the first step, the air quality modeling, is that, with adequate structure, meteorology (e.g., wind speeds and direction, temperature and precipitation) and other factors affecting local pollution formation (e.g., topography) can be captured. One

\footnotetext{
${ }^{31}$ For example, mortality impacts account for upwards of 85 percent of total air pollution damage estimates in US EPA (2011), EC (1999), World Bank and State Environmental Protection Agency of China (2007), Watkiss et al. (2005).
} 
possible drawback is that to date these models, at least at a global scale, tend to aggregate population exposure over large regions, rather than incorporating the fine spatial population data needed to develop damages on a country-by-country basis. And from the perspective of providing policymakers with practical tools, the results from computational air quality models are not easily replicated by those outside of the modeling teams, which may hinder understanding of the key reasons why environmental damages differ across countries and how different assumptions over disputed parameters affect the results. The discussion here focuses on an alternative, reduced form, approach (readily incorporated into a spreadsheet tool) based on extrapolating 'intake fractions' - the fraction of emissions ultimately inhaled by exposed populations - for different countries. The approach is described below, along with other steps, and some estimates of pollution damages.

\section{Intake Fractions}

Basically the approach involves extrapolating intake fractions to other countries, using regression coefficients for a benchmark country, and data on explanatory variables for other countries. Easily (and not surprisingly) the most important explanatory variables are the numbers of people living at different distance classifications from coal plants (it is important to consider people living up to 2,000 km or more from plants given the potentially long-range atmospheric transport of pollution). Also of potential relevance are meteorological variables, and local ammonia concentrations (which catalyze transformations of $\mathrm{SO}_{2}$ and $\mathrm{NO}_{\mathrm{x}}$ into particulates), though there are limits to spatially disaggregated data on these variables to map to the location of individual power plants.

As regards regression coefficients for a baseline country, those in Zhou et al. (2006) for China are viewed as a good starting point (e.g., Cropper et al. 2012). They obtained these coefficients by first calculating intake fractions (separately for direct $\mathrm{PM}_{2.5}, \mathrm{SO}_{2}$ and $\mathrm{NO}_{\mathrm{x}}$ ) for a representative sample of coal plants, using a detailed air quality model (CALPUFF) applied to China matched to spatially disaggregated population data, and then running regressions of these intake fractions on populations residing at four distance classifications from each plant, and other variables.

Parry et al. (2014) used these coefficients to extrapolate intake fractions to other countries, adjusting for population exposure. The latter was calculated by mapping the geographic location of coal plants in about 110 different countries (from the Carbon Monitoring for Action database, covering three quarters of global, coal-fired electricity), to population counts by grid cell (from the LandScan data) for these 110 countries (and countries at risk of cross-border pollution). This approach provides detailed estimates of population exposure for different countries. But important concerns include the reliability of the Zhou et al. (2006) regression coefficients, and potential biases from the failure to adjust for meteorology and ammonia concentrations. Nonetheless, some checks (Parry et al., 2014, Ch. 4) with simulations from a regional air quality model that does take these other factors 
into account suggest there is no systematic pattern to the biases and any bias in many individual cases may not be that large.

\section{Baseline Health Status and Sensitivity to Pollution Exposure}

Inhaling fine particulates increases mortality rates for four main diseases-ischemic heart disease (from reduced blood supply), obstructive pulmonary disease, strokes, and lung cancer-the greater the baseline mortality rates for these diseases, the greater the health damage from pollution exposure. Figure 4 shows estimates of these baseline mortality rates by region.

At a global average level, the total mortality rate for diseases potentially worsened by pollution is 3.7 deaths per 1,000 people per year in 2010 (most of these deaths, 89 percent of them, would still occur with no pollution). Eastern European countries have the highest mortality rate (making people there the most vulnerable to pollution exposure), 10.6 deaths per 1,000 people, in part because of the high prevalence of illnesses caused by smoking and alcohol. On the other hand, the mortality rate is relatively low (1.3 deaths per 1,000 people) in eastern sub-Saharan Africa, where people tend to die from other causes before living long enough to die from pollution-related illness. The biggest cause of mortality is heart disease, which accounts for about half of total deaths at the global level, with pulmonary disease and stoke each accounting for about 20 percent, and lung cancer 10 percent.

A key question is how sensitive are these mortality rates to pollution exposure. A number of widely cited studies for the United States have estimated concentration-response functions for the different diseases, that is, the relationship between increased mortality rates and ambient fine particulate concentrations. ${ }^{32}$ For example, based on an analysis that attributed health outcomes for a large cohort of individuals across 61 US cities, and over a long period of time, to pollution exposure versus other factors, Pope et al. (2002) estimated that each 1 microgram increase in ambient $\mathrm{PM}_{2.5}$ concentrations increases combined annual mortality risks from the above four diseases by 0.6 percent. Based on more recent evidence (e.g., Krewski et al. 2009, Lepeule et al. 2012) the US Environmental Protection Agency now assumes each 1 microgram increase in ambient $\mathrm{PM}_{2.5}$ concentrations raises all-cause mortality rates by 1.06 percent (US EPA 2011, Ch. 5).

As regards regions outside of the United States, Burnett et al. (2013) compiled evidence on concentration response functions from a variety of different empirical studies for different countries (e.g., from studies of exposure to outdoor air pollution, indoor air pollution, and tobacco smoke, with exposure converted to $\mathrm{PM}_{2.5}$ equivalents). A best

\footnotetext{
${ }^{32}$ Intake fractions are easily related to ambient concentrations through breathing rates (e.g., 20 cubic meters of air per day).
} 
statistical fit of all this evidence for each disease ${ }^{33}$ suggests that each 1 microgram increase in ambient $\mathrm{PM}_{2.5}$ concentrations increases all-cause mortality by about 1 percent. While this may represent a reasonable summary of existing evidence, it should be emphasized that considerable uncertainty still surrounds pollution/mortality relationships.

The other noteworthy issue here is that, although at lower pollution concentration levels the concentration-response function appears to be approximately linear, it may flatten out at high pollution concentration levels, if people's ability to absorb additional pollution becomes saturated. Paradoxically, this would imply (given other factors) lower marginal damages, the greater the pollution concentration. The evidence on this, however, is mixed (e.g., Goodkind et al. 2012) and in any case, this possibility may have little relevance for estimating corrective fuel taxes, at least if those taxes are effective (as they should be) enough to lower pollution levels into the region where the concentration-response function is approximately linear.

\section{Monetizing Health Effects}

Although contentious, placing a monetary value on health risks in different countries is needed to estimate efficient tax levels. A good place to start is the meta-analysis of several hundred studies of the value of a statistical life (VSL) conducted in OECD (2010). All of the VSL estimates in the OECD database, which cover a variety of countries (though mainly advanced ones), use stated preference techniques which tend to yield (for reasons that remain a puzzle) significantly lower VSL values than revealed preference studies (the latter type of studies are largely confined to the United States).

Averaged across developed countries, OECD (2010) puts the VSL at \$3.7 million for 2010 (updated from their 2005 figure). They also estimate the income elasticity of the VSL at 0.8, which Parry et al. (2014) use to extrapolate VSL values to all countries based on their GDP per capita relative to that for the developed country average. ${ }^{34}$

\section{$\mathrm{SO}_{2}$ Damage Estimates}

Figure 5 shows estimates (from Parry et al. 2014) for selected countries of damages per ton of $\mathrm{SO}_{2}$ coal plant emissions for 2010 based on the above approach. Cross-country differences in these damage estimates are large, underscoring the heterogeneity in local factors.

\footnotetext{
${ }^{33}$ Performed by Nicholas Muller for Parry et al. (2014).

34 For comparison, Viscusi and Aldy (2003) put the income elasticity between 0.6 and 1.0. For the extrapolations, relative GDP should be based on purchasing power parity rather than market exchange rates as the former better reflects people's willingness to reduce consumption to lower health risks.
} 
The United States and China, with damages of $\$ 17,000$ and $\$ 22,000$ per ton, respectively, are intermediate cases. ${ }^{35}$ In these estimates, China's VSL is taken to be about one-quarter of that for the United States, but average population exposure to emissions is six times as high.

Damages are upwards of \$35,000 per ton in Japan, Poland, Korea, and the United Kingdom, and over $\$ 50,000$ per ton in Germany. This reflects much higher population exposure to emissions in these densely populated countries (more than outweighing any influence of lower mortality values). On the other hand, due to some combination of lower mortality values and lower population exposure (especially in cases where much pollution disperses offshore), damages per ton for Australia, Brazil, Chile, Kazakhstan, Mexico and South Africa are much lower than in the United States (about \$1,500 to \$3,000).

\section{Emissions Factors}

Assessing country-level emissions factors is critically important, especially for coal, given cross-country variability in the use of emissions control technologies at power plants and the pollution content of fuels. The International Institute for Applied Systems Analysis (IIASA) has developed an international database which can be used to estimate countryspecific emissions factors for representative coal plants both with, and without, control technologies, and a weighted average across the two.

Figure 6 shows estimates of $\mathrm{SO}_{2}$ emission rates from this database for coal plants in selected countries for 2010. The first striking (but not surprising) feature is the large difference between emission rates at plants with controls relative to rates at plants with no controls (the total length of the three bars): these technologies typically remove 80-90 percent or more of emissions. The other striking (but again not surprising) feature is the cross-country differences in emission rates. For example, average emission rates in Turkey are about 4.5 times as high as those in the United States, due to the higher average sulfur content of coal, and the smaller share of coal combusted at plants with controls.

\section{(ii) Other Stationary Sources and Ground-Level Emissions}

Damages from gas-fired power plants can be quantified in the same way, and using the same data sources, as just described for coal plants. ${ }^{36}$ For practical purposes the key difference is the much lower emission factors in the latter case-gas combustion produces essentially no direct $\mathrm{PM}_{2.5}$ or $\mathrm{SO}_{2}$ emissions, and lower rates of $\mathrm{NO}_{\mathrm{x}}$ per unit of energy than

\footnotetext{
${ }^{35}$ For China, the damage estimate is broadly consistent with Nielson and Ho (2013).

${ }^{36}$ Estimation of air pollution damages from coal combustion at sources other than power plants (e.g., metals smelting) is hampered by lack of an international database on the geographical location of those sources.
} 
coal (the distinction between plants with and without emissions controls is correspondingly less important for gas plants).

Other major sources of outdoor fossil fuel air emissions include residences - here the focus is on emissions from natural gas - and vehicles. In both cases, emissions are released fairly close to the ground and tend to remain locally concentrated, which greatly simplifies estimation of intake fractions. Parry et al. (2014) extrapolated intake fractions for these sources to the country level using a database of intake fractions for 3,464 urban centers compiled in Apte et al. (2012).

\section{B. Other Externalities from Road Vehicles}

\section{(i) Congestion}

Establishing comparable, cross-country assessments of congestion costs for the purposes of assessing fuel taxes is extremely challenging, as there is no international database consistently measuring travel delays (or alternatively differences between actual and free flow travel speeds), for road classes and times of day, that can be aggregated into nationwide average measures of travel delay on a country-by-country basis.

Given this severe data constraint, Parry et al. (2014) used regression analyses to obtain a very coarse extrapolation of nationwide average travel delays. This was done by first estimating statistical relationships between observed average travel delays and various transportation indicators using a database of transportation characteristics for over 90 cities across developed and developing countries. The regression coefficients were then combined with nationwide measures (where available, extrapolated if not) of the same transportation indicators to project nationwide travel delays.

The next step is to convert average travel delays (which drivers consider) into marginal delays (which they do not), that is the delay that one driver imposes on other road users. Based on aggregate relationships that have been fitted across urban areas, a reasonable rule of thumb appears to be that marginal delay is about four times the average delay, perhaps with plausible range of around 2 to $5 .^{37}$

\footnotetext{
${ }^{37}$ See for example Small and Verhoef (2007), pp. 69-83. A further complication is that travel on busy roads (which is frequently dominated by commuting) tends to be less responsive to fuel prices than driving on free flowing roads. Parry et al. (2014) scale back the congestion benefits from fuel pricing by one-third to make a rough adjustment for this (based loosely on evidence about the relative responsiveness to fuel pricing of peak and off-peak driving).
} 
Marginal congestion costs can then be calculated from the product of marginal delay and the value of travel time (VOT). Based on empirical literature (summarized in Small and Verhoef 2007, pp. 52-53), a reasonable rule of thumb seems to be that the VOT for urban driving is about 60 percent of the market wage (cross-country wage data is available from the International Labor Organization), though there is a fair amount of variation across studies, and evidence for developing countries is sparse.

Each of the three steps above is debatable, though it is easy (below) to infer the implications of alternative assumptions. ${ }^{38}$ And in several ways, the above approach likely understates (marginal) congestion costs. It ignores the possibility that buses (which have high vehicle occupancies) constitute a significant share of vehicle traffic, which increases the delay one driver imposes on other road users (Parry et al. 2014, pp. 121-123) and the possibility that congestion causes broader costs through travel time variability and inducing people to leave earlier or later than they would otherwise prefer (e.g., Fosgerau et al. 2008, Peer, Koopmans, and Verhoef 2012).

\section{(ii) Accidents}

The externality from traffic accidents is less clear cut than for traffic congestion. It is generally assumed that motorists do not consider injury risks to pedestrians when deciding how much to drive, but they do consider injury risks to themselves in single-vehicle collisions. They may also consider injury risks to themselves in multi-vehicle collisions but not risks to other vehicle occupants - however, the latter risks are reduced to the extent that extra driving by one motorist causes others to drive slower or more carefully due to reduced vehicle headways. Some portion of property damages and medical costs is borne by individuals through elevated future insurance rates, co-payments etc. but the rest is borne by third parties (insurance companies and the government).

Parry et al. (2014) obtain a rudimentary measure of accident externalities by first using data from the International Road Federation (IRF 2009) on fatalities to pedestrians/cyclists and car occupants for different countries ${ }^{39}$ and assuming 100 percent, and 25 percent, respectively, of these deaths are external, and monetizing the result using VSLs. Secondly, they then infer other external costs (for non fatal injuries, third party property and medical costs) based on extrapolations of the ratio of these costs to external fatality costs from several country case studies (adjusting for share of vehicle occupant versus pedestrian/cyclist deaths).

\footnotetext{
${ }^{38}$ For example, if congestion accounts for 50 percent of the corrective fuel tax and a VOT equal to 40 percent (rather than 60 percent) of the wage is used, the corrective fuel tax would be 15 percent lower.

${ }^{39}$ For developing countries in particular, the IFR data may significantly understate fatalities due to underreporting.
} 
Annualized spending on highway maintenance provides a rough proxy for road damage, and this is available for many countries in IRF (2009). Parry et al. (2014) attribute half of this damage to heavy vehicle traffic, and half to weather and natural decay of materials (a more sophisticated approach would relate these shares to local climate conditions, though this would have little effect on corrective fuel tax estimates given the dominance of other externalities).

\section{(iv) Miscellaneous data}

The above discussion focuses on congestion and accident costs for cars. For trucks, which take up more road space and are driven slower but are less likely to be in peak urban traffic, congestion costs per vehicle mile are usually taken to be about twice those for cars (e.g., Lindsey 2010, pp. 363). As for external accident costs per vehicle mile, Parry et al. (2014) assume they are the same for trucks as for cars: the former are more deadly in a given collision, but crash less often. The breakout of diesel fuel use by cars versus trucks (needed to average over truck and diesel car externalities) is available from ICCT (2010) for countries in some cases, and for regional country averages in others.

Finally, as noted above, an important parameter needed to compute corrective motor fuel taxes is the fraction of the tax-induced reduction in fuel use that comes from reductions in vehicle travel (as opposed to the fraction coming from long-run improvements in average, on-road, vehicle fuel efficiency). Based on available evidence, Parry et al. (2014) assume this fraction is 0.5 for gasoline and 0.6 for diesel (implying, for example, that congestion and accident externalities are scaled back by 50 percent in computing corrective gasoline taxes).

\section{Corrective Energy Taxes in Different Countries and Their Impacts}

This section provides a flavor of what efficient energy tax systems might look like in different countries and the gains from policy reform, using results from Parry et al. (2014). As previously emphasized, these corrective tax estimates should be viewed as a starting point for discussion and refinement, given numerous uncertainties and controversies, though they likely give a reasonable sense of the appropriate direction of efficient tax reform.

\section{A. Corrective Tax Estimates}

(i) Coal 
Figure 7 shows estimates of corrective taxes on coal use for selected countries, expressed in US \$ per gigajoule (GJ) for $2010 .{ }^{40}$ Also shown are current coal taxes, but these are essentially zero or slightly negative-unlike for motor fuels, no country imposes substantial excises on coal. To put the estimates in perspective, the average world coal price in 2010 was around $\$ 5$ per GJ.

The charges on coal for global warming, based on an illustrated value of \$35 per ton of $\mathrm{CO}_{2}$ inferred from US IAWG (2012) ${ }^{41}$, are large at $\$ 3.3$ per GJ, or two-thirds of the world coal price. Damages per GJ are essentially constant across countries, given practically no variation in carbon emission rates per GJ, and the damage per ton of $\mathrm{CO}_{2}$ is the same, regardless of where emissions come from (this ignores the possible equity case for setting lower rates in low income countries when there are constraints on international transferssee Gillingham and Keen 2012).

More striking however are the charges for local air pollution because of their size in many cases, but also the substantial variation across countries. For 10 of the countries shown in Figure 7, local air pollution damages exceed the carbon damages, and in six cases air pollution charges are more than double the carbon charge. On the other hand, air pollution charges are less than $\$ 2$ per GJ in five cases. ${ }^{42}$

The differences in damages per ton of air pollution emissions was discussed abovemost importantly, they depend on population exposure (which tends to be high in populous developing countries), and the VSL (higher in high-income countries), while baseline mortality rates for illnesses whose prevalence is increased by inhaling pollution (relatively high in eastern Europe, relatively low in Africa) are also significant. In addition to these factors, the corrective coal tax estimates in Figure 7 also vary across countries due to differences in emission rates (which tend to be higher in developing countries due to less deployment of emissions control technologies). So for example, high air pollution damages in China (\$11.7 per GJ) are explained by high population exposure and high emission rates, while the opposite applies to Australia (\$0.8 per GJ), where emissions largely disperse over the oceans or sparsely populated areas.

\footnotetext{
${ }^{40}$ This provides a cleaner comparison, given that emission rates per ton of coal vary across countries depending on the type of coal used.

${ }^{41}$ For further discussion see Nordhaus (2014), who estimates a lower value (about $\$ 20$ per ton in 2010\$).

${ }^{42}$ One important caveat here is that damages are based on currently observed emission rates, which average over plants and with and without emissions controls. These rates would fall significantly with the imposition of corrective air pollution charges and credits for control technologies.
} 
The United States is an intermediate case with pollution damages of \$5.5 per GJ. Average emission rates and population exposure are lower in the United States than China (the intake fraction for $\mathrm{SO}_{2}$ in the United States is one-sixth of that for China) though partially offsetting this is the higher VSL (four times as high in the United States). Perhaps surprisingly, South Africa, has a relatively modest pollution charge (\$1.3 per GJ): average population exposure to emissions in South Africa is similar to that for the United States, but its baseline mortality and VSL are each roughly one-third of those for the United States (though emission rates per GJ of coal are higher).

\section{(ii) Natural Gas}

Figure 8 shows comparable estimates for natural gas, again expressed per GJ. Like coal, gas is not subject to large excises and, as noted in Section 2, some countries (mostly in the Middle East and North Africa) heavily subsidize gas. For perspective, the average world gas price was also about \$5 per GJ in 2010.

The key point from this figure is that, although natural gas is undercharged, the degree of undercharging is generally far less pronounced for gas than for coal, due to lower emission rates. The carbon charge is $\$ 1.9$ per GJ (35 percent of the world price) as carbon emission rates per GJ are about 40 percent lower than for coal. And combusting natural gas produces essentially no $\mathrm{SO}_{2}$ or direct $\mathrm{PM}_{2.5}$ emissions, and $\mathrm{NO}_{\mathrm{x}}$ emission rates per $\mathrm{GJ}$ are generally lower than those for coal.

\section{(iii) Gasoline}

Figure 9 shows estimates of the corrective tax on gasoline for selected countries from Parry et al. (2014) for 2010.

The corrective tax estimates are large-typically around 40 to 80 cents per liter (\$1.60 to \$3.20 per gallon) across developed and developing countries alike. However, carbon and local pollution contribute a relatively modest amount to the corrective tax (8 cents per liter for the former and even less for the latter)-more important are congestion (especially in many developed countries where VOT values are high) and accidents (relatively high in many developing countries with high traffic fatality rates). In most cases, corrective taxes exceed existing taxes, though the opposite applies in several European countries.

Even for the latter cases, it is far from clear that fuel taxes should be scaled back towards their corrective levels. For one thing, corrective taxes are estimated with considerable imprecision providing no more than a ballpark figure which, for reasons noted above, may be understated. For another, for countries with already high fuel taxes, transitioning towards the appropriate mix of fuel and mileage-based taxes (with the latter 
carefully tailored, in particular, to improving traffic flows on heavily congested roads), is far more urgent than fine tuning fuel tax rates to rudimentary estimates of corrective taxes.

\section{(iv) Diesel}

Figure 10 shows estimates of corrective taxes on diesel fuel (averaged across cars and trucks) in \$ per liter for 2010.

In this case the degree of undercharging - the mismatch between current and corrective taxes-is generally more pronounced than for gasoline. In part this is because diesel is often taxed at a lower rate than gasoline. But often (though not always) corrective taxes are higher, for example, due to higher air pollution emission rates and road damage from trucks. ${ }^{43}$

\section{B. Gains from Policy Reform}

Figures 11-13 summarize highly simplified calculations of the health, environmental, and fiscal benefits of moving from current fuel taxes (which are often zero, or negative in some cases) to corrective taxes. ${ }^{44}$

Fuel tax reform can dramatically reduce deaths from local air pollution-by over 50 percent in nine of the countries shown in Figure 11. In most cases, health benefits predominantly reflect reductions in coal use and in emission rates per GJ of coal. Energyrelated $\mathrm{CO}_{2}$ emissions also fall substantially, exceeding 15 percent in all but two cases shown in Figure 12. In all but five countries in this figure, reductions in coal use account for more than half of the $\mathrm{CO}_{2}$ reductions, and more than 85 percent in China, India, Poland and South Africa. The fiscal benefits are also substantial-revenues from corrective fuel taxes exceed 1 percent of GDP in all but two countries in Figure 13, and more than 3 percent in eight countries. The composition of potential revenue differs substantially across countries however: for example, coal taxes are the main source of potential revenue in China, Germany, India, Israel, Kazakhstan, Poland, South Africa, and Turkey, while higher motor

\footnotetext{
${ }^{43}$ Leaving aside externalities, it might be argued, along the lines of Diamond and Mirrlees (1971), that diesel fuel should receive favorable tax treatment relative to gasoline, to the extent it reflects an input in production (a fuel for truck transport) rather than a final consumption good. However, normal procedures under VAT systems would address this as VAT paid on inputs is rebated.

${ }^{44}$ These estimates calculate, on a country-level basis, proportionate changes in the price of fuel products from reforming fuel taxes (using price data in Clements et al. 2013) and simply apply assumptions about fuel price elasticities to infer changes in fuel use (based on data from the International Energy Association), ignoring cross-price effects. Taxes for local pollution are assumed to incentivize the adoption of clean-up technologies at all plants.
} 
fuel taxes are the main source of potential revenues in Brazil, Chile, Egypt, Indonesia, Japan, Mexico, Nigeria, and the United States.

At a global level (averaged across over 150 countries), Parry et al. (2014) estimate that getting energy prices right would reduce pollution-related deaths by 63 percent, energyrelated $\mathrm{CO}_{2}$ emissions by 23 percent, while raising 2.6 percent of GDP in new revenues.

\section{Conclusion}

The message of this paper is that getting energy prices right-using fiscal instruments to reflect both supply costs and environmental damages in energy prices-should form the centerpiece of efforts to mitigate the major externalities from energy use (given other policies, like clean technology $\mathrm{R} \& \mathrm{D}$, road and power grid infrastructure investments).

But getting the design basics right is critical. First, this means targeting the right base, for example, the pollution content of fuels. Second, it means ensuring that fiscal dividends are put to productive use, most obviously, by lowering the burden of broader taxes-green fiscal reform is largely about smarter, not higher, taxes. And third, it means aligning tax rates with external costs, which requires a careful assessment of country-specific factors. There are some design subtleties (e.g., crediting for emissions capture technologies) but the practicalities should be manageable. In fact, these reforms represent a straightforward extension of existing practices for motor fuel excises that are well established in most countries, and among the easiest of all taxes to administer.

Beyond coordinating different government ministries (finance, environment, energy), the challenges lie in getting influential political groups on board. That means a clear communications strategy to inform industry and the public about the benefits from policy reform, why reforms are often in countries' own interests even if implemented unilaterally, and the advantages of fiscal reforms over other approaches. It also means appropriate safeguards for the vulnerable groups, most notably adequate social safety nets for lowincome households. Economists have a key role to play in all of this, through careful quantification of implementable design specifics for different countries, tradeoffs in policy choice, and distributional impacts of policy reform.

\section{References}

Acemoglu, Daron, Philippe Aghion, Leonardo Bursztyn, and David Hemous, 2012. “The Environment and Directed Technological Change.” American Economic Review 102, 131-66. 
Allcott, Hunt, 2014. "Paternalism and Energy Efficiency: An Overview." Working Paper 20363, National Bureau of Economic Research, Cambridge, MA.

Allcott, Hunt and Michael Greenstone, 2012. “Is There an Energy Efficiency Gap?” Journal of Economic Perspectives 26, 3-28.

Apte, Joshua S., Emilie Bornbrun, Julian D. Marshall, and William W. Nazaroff, 2012. "Global Intraurban Intake Fractions for Primary Air Pollutants from Vehicles and Other Distributed Sources.” Environmental Science and Technology 46: 3415-23.

Arnott, Richard A., Tilmann Rave, and Ronnie Schöb, 2005. Alleviating Urban Traffic Congestion. MIT Press, Cambridge, MA.

Baumol, William J. and Wallace E. Oates, 1971. “The Use of Standards and Prices for Protection of the Environment.” Swedish Journal of Economics 73, 42-54.

Bento, Antonio, Mark Jacobsen, and Antung A. Liu, 2012. "Environmental Policy in the Presence of an Informal Sector.” Discussion paper, Cornell University.

Böhringer, C., J.C. Carbone, and T.F. Rutherford, 2012. "Unilateral Climate Policy Design: Efficiency and Equity Implications of Alternative Instruments to Reduce Carbon Leakage.” Energy Economics 34 (Supplement 2): S208-S217.

Bovenberg, A. Lans, and Lawrence H. Goulder, 1996. “Optimal 2001 Environmental Taxes in the Presence of Other Taxes.” American Economic Review 84:1085-9.

Bovenberg, A. Lans, and Lawrence H. Goulder, 2002. "Environmental Taxation and Regulation.” In A. J. Auerbach and M. Feldstein (eds.), Handbook of Public Economics, Elsevier, Amsterdam.

Burnett, Richard T., C. Arden Pope, Majid Ezzati, Casey Olives, Stephen S. Lim, Sumi Mehta, Hwashin H. Shin, and others, 2013. “An Integrated Risk Function for Estimating the Global Burden of Disease Attributable to Ambient Fine Particulate Matter Exposure.” Health Canada, Ottawa, Ontario, Canada.

Brown, Stephen P.A. and Huntington, Hillard G., 2013. “Assessing the US Oil Security Premium.” Energy Economics 38, 118-127.

Busse, Meghan R., Christopher R. Knittel, and Florian Zettelmeyer. 2013. “Are Consumers Myopic? Evidence from New and Used Car Purchases.” American Economic Review 103: 220-56.

Calder, Jack, 2014. “Administration of a US Carbon Tax.” In I. Parry, A. Morris and R. Williams (eds.), Implementing a US Carbon Tax: Challenges and Debates. Routledge, forthcoming, 38-61. 
Clements, Benedict, David Coady, Stefania Fabrizio, Sanjeev Gupta, Trevor Alleyene, and Carlo Sdralevich (eds.), 2013. Energy Subsidy Reform: Lessons and Implications. International Monetary Fund, Washington, DC.

Cropper, Maureen, Shama Gamkhar, Kabir Malik, Alex Limonov, and Ian Partridge, 2012. “The Health Effects of Coal Electricity Generation in India,” Discussion Paper No. 12-15, Resources for the Future, Washington, DC.

Dales, J.H., 1968. Pollution, Property, and Prices. University of Toronto Press.

Dahl, Carol, 2012. "Measuring Global Gasoline and Diesel Price and Income Elasticities.” Energy Policy 41: 2-13.

Diamond, Peter A. and James A. Mirrlees, 1971. "Optimal Taxation and Public Production I: Production Efficiency” and “II: Tax Rules”. American Economic Review 61: 8-27 and 261278.

Dinan, Terry, 2014. “Offsetting a Carbon Tax’s Burden on Low-Income Households.” In I. Parry, A. Morris and R. Williams (eds.), Implementing a US Carbon Tax: Challenges and Debates. Routledge, forthcoming, 38-61.

Ekins, Paul and Stefan Speck (Eds.), 201. Environmental Tax Reform: A Policy for Green Growth. Oxford University Press, Oxford.

EC, 1999. ExternE Externalities of Energy, Vol. 7-Methodology Update. Report produced for the European Commission, DG XII. Brussels: Office of Publications for the European Communities.

Ezzati, Majid, 2005. “Indoor Air Pollution and Health in Developing Countries.” Lancet 366: 104, 106.

Feldstein, Martin, 1995. "The Effect of Marginal Tax Rates on Taxable Income: A Panel Study of the 1986 Tax Reform Act.” Journal of Political Economy 103: 551-72.

Feldstein, Martin, 1999. “Tax Avoidance and the Deadweight loss of the Income Tax." Review of Economics and Statistics LXXXI: 674-680.

Fischer, Carolyn, and Richard G. Newell, 2008. "Environmental and Technology Policies for Climate Mitigation.” Journal of Environmental Economics and Management 55: 142-62.

Fischer, Carolyn, Richard Morgenstern, and Nathan Richardson, 2013. "Carbon Taxes and 
Energy Intensive Trade Exposed Industries: Impacts and Options,” Working paper, Resources for the Future, Washington, DC.

Fosgerau, M., K. Hjorth, C. Brems, and D. Fukuda, 2008. Travel Time Variability: Definition and Valuation. DTU Transport, Lyngby, Denmark.

Fullerton, Don and Gilbert E. Metcalf, 2001. "Environmental Controls, Scarcity Rents, and Pre-Existing Distortions.” Journal of Public Economics 80: 249-267.

Fullerton, Don, Andrew Leicester, and Stephen Smith, 2008. "Environmental Taxes.” NBER Working Paper No. 14197, National Bureau of Economic Research, Cambridge, MA.

Fullerton, Don and Garth Heutel, 2007. "The General Equilibrium Incidence of Environmental Taxes.” Journal of Public Economics 91: 571-591.

Gillingham, Robert and Michael Keen, 2012. "Mitigation and Fuel Pricing in Developing Countries.” In I. Parry, R. de Mooij, and M. Keen (eds), Fiscal Policy to Mitigate Climate Change: A Guide for Policymakers. International Monetary Fund, Washington, DC.

Goodkind, Andrew L., Jay S. Coggins, Timothy A. Delbridge, Milda Irhamni, Justin Andrew Johnson, Suhyun Jung, Julian Marshall, Bijie Ren, and Martha H. Rogers, 2012. "Prices vs. Quantities with Increasing Marginal Benefits.” Discussion paper, Department of Applied Economics, University of Minnesota.

Goulder, Lawrence H., Ian W.H. Parry, Roberton C. Williams, and Dallas Burtraw, 1999. "The Cost-Effectiveness of Alternative Instruments for Environmental Protection in a Second-Best Setting.” Journal of Public Economics 72: 329-360.

Gruber, Jonathan and Emmanuel S. Saez, 2002. "The Elasticity of Taxable Income: Evidence and Implications.” Journal of Public Economics 84: 1-32.

Harberger, Arnold C., 1964. “The Measurement of Waste.” American Economic Review 54: 58-76.

Hassett, Kevin, Aparna Mathur, and Gilbert Metcalf, 2009. “The Incidence of a U.S. Carbon tax: a Lifetime and Regional Analysis.” The Energy Journal 30: 155-178.

Helfand, Gloria, and Ann Wolverton, 2011. "Evaluating the Consumer Response to Fuel Economy: A Review of the Literature.” International Review of Environmental and Resource Economics 5: 103-146. 
Hepburn, Cameron, 2006. "Regulation by Prices, Quantities, or Both: A Review of Instrument Choice.” Oxford Review of Economic Policy 22, 226-47.

ICCT, 2010. Global Transportation Roadmap Model. International Council on Clean Transportation, Washington, DC.

IEA, 2014. World Energy Statistics and Balances. International Energy Agency, Paris, France.

IRF, 2009. World Road Statistics 2009. International Road Federation, Geneva, Switzerland.

Keen, Michael, Ian W.H. Parry and Jon Strand, 2013. “Ships, Planes, and Taxes.” Economic Policy 28 701-749.

Kneese, Allen V. and Blair T. Bower, 1968. Managing Water Quality: Economics, Technology, Institutions. Johns Hopkins Press.

Krewski, Daniel, Michael Jerrett, Richard T. Burnett, Renjun Ma, Edward Hughes, Yuanli Shi, Michelle C. Turner, C. Arden Pope III, George Thurston, Eugenia E. Calle, and Michael J. Thun, 2009. "Extended Follow-Up and Spatial Analysis of the American Cancer Society Study Linking Particulate Air Pollution and Mortality.” Research Report 140 (Boston, MA Health Effects Institute). http://scientificintegrityinstitute.net/Krewski052108.pdf.

Krupnick, Alan J., Margaret Walls, Ian Pary, Tony Knowles and Kristin Hayes, 2010. Toward a New National Energy Policy: Assessing the Options. Resources for the Future and National Energy Policy Institute, Washington, DC.

Lepeule, J., F. Laden, D. Dockery, and J. Schwartz, 2012. "Chronic Exposure to Fine Particles and Mortality: An Extended Follow-up of the Harvard Six Cities Study from 1974 to 2009.” Environmental Health Perspectives 120: 965-70.

Lindsey, Robin, 2006. "Do Economists Reach A Conclusion on Road Pricing? The Intellectual History of an Idea.” Economic Journal Watch 3: 292-379.

Lindsey, Robin, 2007. "Congestion Relief: Assessing the Case for Road Tolls in Canada." No. 248. Toronto: C.D. Howe Institute Commentary.

Lindsey, Robin, 2010. “Dedicated Lanes, Tolls and Its Technology.” In The Future of Interurban Passenger Transport. Organization for Economic Cooperation and Development, Paris. 
Liu, Gang, 2004. "Estimating Energy Demand Elasticities for OECD Countries: A Dynamic Panel Data Approach.” Discussion Paper No. 373, Statistics Norway.

Mathur, Aparna, and Adele C. Morris, 2014. "Distributional Effects of a Carbon Tax in Broader U.S. Fiscal Reform.” Energy Policy 66: 326-334.

McKinsey and Company, 2014. Greenhouse Gas Abatement Cost Curves. Available at: www.mckinsey.com/client_service/sustainability/latest_thinking/greenhouse_gas_abatement _cost_curves.

Metcalf, Gilbert E., 2009. "Designing a Carbon Tax to Reduce US Greenhouse Gas Emissions.” Review of Environmental Economics and Policy 3: 63-83.

Metcalf, Gilbert and David Weisbach. 2009. "The Design of a Carbon Tax.” Harvard Environmental Law Review 33: 499-556.

Montgomery, W. David, 1972. "Markets in Licenses and Efficient Pollution Control Programs.” Journal of Economic Theory 5: 395-418.

Muller, Nicholas Z., and Robert Mendelsohn, 2012. "Efficient Pollution Regulation: Getting the Prices Right”. American Economic Review 99: 1,714-39,

Muller, Nicholas Z., and Robert Mendelsohn, 2012. Using Marginal Damages in Environmental Policy: A Study of Air Pollution in the United States. American Enterprise Institute, Washington DC.

Nemet, Gregory F., Tracey Holloway and Paul Meier, 2010. "Implications of Incorporating Air-Quality Co-Benefits into Climate Change Policymaking." Environmental Research Letters 5: 1-9.

Newbery, David M., 2005. "Why Tax Energy? Towards a More Rational Policy." The Energy Journal 26: 1-40.

Nielsen, Chris P., and Mun S. Ho, eds., 2013. Clearer Skies over China: Reconciling Air Quality. Climate, and Economic Goals. MIT Press, Cambridge, Massachusetts.

Nordhaus, William D., 2002. "Modeling Induced Innovation in Climate-Change Policy.” In Arnulf Grubler, Nebojsa Nakicenovic, and William Nordhaus (eds.), Technological Change and the Environment, Resources for the Future, Washington, DC, 182-209.

Nordhaus, William D., 2007. "To Tax or Not to Tax: Alternative Approaches to Slowing Global Warming.” Review of Environmental Economics and Policy 1: 26-44. 
Nordhaus, William D., 2013. "Estimates of the Social Cost of Carbon: Concepts and Results from the DICE-2013R Model and Alternative Approaches." Journal of the Association of Environmental and Resource Economists 1: 273-312.

NRC, 2009. The Hidden Costs of Energy. National Research Council, Washington, DC.

Oates Wallace E. and Diana L. Strassmann,1984. "Effluent Fees and Market Structure.” Journal of Public Economics 24: 29-46.

OECD, 2010. Taxation, Innovation and the Environment. Organization for Economic Cooperation and Development, Paris.

OECD, 2013. Environmentally Related Taxes, Fees and Charges Database. Organization for Economic Cooperation and Development, Paris. Available at: http://www2.oecd.org/ecoinst/queries.

OECD, 2014. The Distributional Incidence of Energy Taxes. Organization for Economic Cooperation and Development, Paris.

Opschoor J. B., and H.B. Vos, 1989. Economic Instruments for Environmental Protection. Organization for Economic Cooperation and Development, Paris.

Parry, Ian W.H. and Antonio M. Bento, 2000. "Tax Deductions, Environmental Policy, and the "Double Dividend" Hypothesis." Journal of Environmental Economics and Management 39: 67-96.

Parry, Ian W.H., William A. Pizer, and Carolyn Fischer, 2003. "How Large Are the Welfare Gains from Technological Innovation Induced by Environmental Policies?” Journal of Regulatory Economics 23: 237-55.

Parry, Ian W.H., David Evans, and Wallace Oates, 2014. "Are Energy Efficiency Standards Justified?” Journal of Environmental Economics and Management 67: 104-125.

Parry, Ian W.H., Dirk Heine, Shanjun Li, and Eliza Lis, 2014. Getting Energy Prices Right: From Principle to Practice. International Monetary Fund, Washington, DC.

Parry, Ian W.H., Chandara Veung, and Dirk Heine, 2014. "How Much Carbon Pricing is in Countries' Own Interests? The Critical Role of Co-Benefits.” Working paper, International Monetary Fund, Washington, DC. 
Parry, Ian W.H., Roberton C. Williams and Lawrence H. Goulder, 1999. "When Can Carbon Abatement Policies Increase Welfare? The Fundamental Role of Distorted Factor Markets." Journal of Environmental Economics and Management 37: 52-84.

Parry, Ian W.H. and Roberton Williams, 2010. "What are the Costs of Meeting Distributional Objectives for Climate Policy?” B.E. Journal of Economic Analysis \& Policy 10, Issue 2 (Symposium), Article 9.

Peer, S., C.C. Koopmans, and E.T. Verhoef, 2012. "Prediction of Travel Time Variability for Cost-Benefit Analysis.” Transportation Research Part A: Policy and Practice 46: 79-90.

Pizer, William A., 2002. "Combining Price and Quantity Controls to Mitigate Global Climate Change.” Journal of Public Economics 85: 409-34.

Pizer, William A. and David Popp, 2008. "Endogenizing Technological Change: Matching Empirical Evidence to Modeling Needs.” Energy Economics 30: 2,754-2,770.

Pope C.A. III, Burnett R.T., Thun M.J., Calle E.E., Krewski D., Ito K., et al. 2002. "Lung Cancer, Cardiopulmonary Mortality, and Long-Term Exposure to Fine Particulate Air Pollution.” Journal of the American Medical Association 287:1132-1141.

Saez, Emmanuel, Joel Slemrod, and Seth H. Giertz, 2012. "The Elasticity of Taxable Income with Respect to Marginal Tax Rates: A Critical Review.” Journal of Economic Literature 50: 3-50.

Sallee, James, 2014. "Rational Inattention and Energy Efficiency." Journal of Law and Economics, forthcoming.

Sallee, James, Sarah West, and Wei Fan, (2009). "Consumer Valuation of Fuel Economy: A Microdata Approach.” Working Paper, University of Chicago (September).

Santos, Georgina. 2004 (ed.). Road Pricing: Theory and Evidence, vol. 9, Research in Transportation Economics. Elsevier, San Diego, CA.

Small, Kenneth A., and Erik Verhoef, 2007. The Economics of Urban Transportation. Routledge, New York.

Stavins, Robert N., 2007. "A U.S. Cap-and-Trade System to Address Global Climate Change.” Hamilton Project Discussion paper, Brookings Institution, Washington, DC.

Sterner Thomas, 2002. Policy Instruments for Environmental and Natural Resource Management. Resources for the Future, Washington DC. 
Sterner, Thomas, 2007. "Fuel Taxes: An Important Instrument for Climate Policy.” Energy Policy 35: 3194-3202.

TRB, 2006. The Fuel Tax and Alternatives for Transportation Funding. Transportation Research Board, National Research Council, Washington, DC.

Trüby Johannes and Paulus Moritz, 2011. "Market Structure Scenarios in International Steam Coal Trade.” Working paper 11/02, Institute for Energy Economics at the University of Cologne.

US EPA, 2011. The Benefits and Costs of the Clean Air Act from 1990 to 2020. Report to Congress, United States Environmental Protection Agency, Washington, DC.

Viscusi, W. Kip and Joseph E. Aldy, 2003. "The Value of a Statistical Life: A Critical Review of Market Estimates throughout the World.” Journal of Risk and Uncertainty 27: 576.

Watkiss, Paul, Steve Pye, and Mike Holland, 2005. CAFE (Clean Air for Europe) CBA: Baseline Analysis 2000 to 2020. Report to the European Commission (Brussels: DirectorateGeneral for the Environment).

WHO, 2014. Public Health, Environmental and Social Determinants of Health. World Health Organization, available at: www.who.int/phe/health_topics/outdoorair/databases/en/.

Woodcock, James, et al. 2009. "Public Health Benefits of Strategies to Reduce GreenhouseGas Emissions: Urban Land Transport.” Health and Climate Change 2, 374: 1930-1943.

World Bank and State Environmental Protection Agency of China, 2007. Cost of Pollution in China: Economic Estimates of Physical Damages. World bank, Washington DC.

Zhou Ying, Jonathan I. Levy, John S. Evans, and James K. Hammitt, 2006 “The Influence of Geographic Location on Population Exposure to Emissions from Power Plants throughout China.” Environment International 32: 365 - 373. 


\section{Box 1. Some Broader Externalities Associated with Fossil Fuel Energy}

The discussion here by-passes a variety of other externalities associated with fossil fuel energy. Examples include:

Active living benefits from travel mode shifting. City-level studies (e.g., Woodcock et al. 2009) suggest there are substantial health benefits when individuals shift away from car trips to other travel modes involving physical exercise, including biking, walking, and walking to transit stops. However, much of the behavioral response to motor fuel taxes reflects other factors (e.g., longer run improvements in vehicle fuel economy, car pooling, combining car trips, using transit with minimal walking distance to stops) and people may internalize at least some of the health benefits in their travel mode decisions.

Environmental impacts from fuel extraction, storage, and transportation. Adverse side effects here include de-spoiling of the natural environment at mining and drilling sites, toxic releases from mine tailings and fuel processing wastes, leakage from fuel storage tanks, oil spills, etc. However, these types of external costs appear to be small in magnitude relative to external costs considered here (e.g., NRC 2009) and they are better addressed through other instruments than fuel taxes (e.g., double hull requirements for tankers, requirements that mined areas are returned to their natural state).

Energy security. The external costs of foreign energy dependence have always been opaque, and more so as expanding supplies of unconventional oil and gas reduce the share of global supplies coming from regions that might be viewed as unstable. In individual cases, policies to promote greater diversity in energy supply may make sense, but it is difficult to develop consistent, crosscountry estimates of taxes to correct for energy security concerns. For some discussion in the US context, though with relatively modest implications for energy taxation, see Brown and Huntington (2013).

Indoor air pollution. The World Health Organization (WHO 2014) estimates that even more people die prematurely from inhaling indoor air pollution (e.g., fumes from fuel burning in cooking stoves) than from outdoor air pollution. But again, to what extent indoor air pollution-where the households causing pollution are mostly the ones affected by it-should be viewed as an external cost is not entirely clear. Moreover, there is a risk that high prices for taxed fossil fuels may cause switching to untaxed fuels (e.g., biomass, garbage) with equally, or perhaps worse, health effects. More pressing policies might include, for example, incentives for better ventilated stoves and clean fuel alternatives (e.g., Ezzati 2005).

Terms of trade effects. If a group of countries collectively price carbon emissions this can result in lower international fuel prices and a transfer from fuel exporters to fuel importers-effectively, a worsening of the terms of trade for the former. From a national welfare perspective, this would represent a co-cost rather than a co-benefit for exporters. But these costs are not considered here as they are tricky to estimate- they depend, for example, on how many countries price carbon and how fuel supply (often in administered markets) responds. 
Table 1. $\mathrm{CO}_{2}$ Mitigation Opportunities Exploited by Different Policies

\begin{tabular}{|c|c|c|c|c|c|c|c|}
\hline \multirow[b]{3}{*}{ Policy instrument } & \multicolumn{4}{|c|}{ Power generation } & \multicolumn{2}{|c|}{ Trans portation } & \multirow{3}{*}{$\begin{array}{l}\text { Homes/ } \\
\text { industry } \\
\\
\text { reduced } \\
\text { fuel } \\
\text { demand }\end{array}$} \\
\hline & \multirow{2}{*}{\multicolumn{2}{|c|}{ 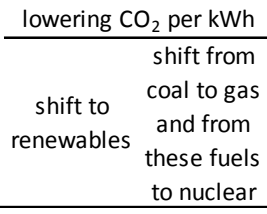 }} & \multicolumn{2}{|c|}{ reducing electricity use } & \multirow[b]{2}{*}{$\begin{array}{l}\text { higher } \\
\text { fuel } \\
\text { economy }\end{array}$} & \multirow[b]{2}{*}{$\begin{array}{l}\text { reduced } \\
\text { driving }\end{array}$} & \\
\hline & & & $\begin{array}{l}\text { higher } \\
\text { efficiency }\end{array}$ & $\begin{array}{l}\text { reduced } \\
\text { product use }\end{array}$ & & & \\
\hline (1) Carbon tax & $\boldsymbol{v}$ & $\mathbf{v}$ & $\sqrt{ }$ & $\boldsymbol{v}$ & $\sqrt{ }$ & $\sqrt{ }$ & $\sqrt{ }$ \\
\hline (2) Renewable subsidy & $\mathbf{v}$ & - & - & - & - & - & - \\
\hline (3) CO2 per kWh standard & $\mathbf{v}$ & $\sqrt{ }$ & $(\sqrt{ })$ & (v) & - & - & - \\
\hline (4) Efficiency standards for buildings, appliances, etc. & - & - & $\mathbf{v}$ & $x$ & - & - & - \\
\hline (5) Vehicle fuel efficiency standard & - & - & - & - & $\sqrt{ }$ & $x$ & - \\
\hline (6) Combination of (3), (4), (5) & $\sqrt{ }$ & $\boldsymbol{v}$ & $\boldsymbol{v}$ & $x$ & $\sqrt{ }$ & $x$ & - \\
\hline (7) Electricity tax & - & - & $\sqrt{ }$ & v & - & - & - \\
\hline (8) Motor fuel tax & - & - & - & - & $\boldsymbol{v}$ & $\mathbf{v}$ & - \\
\hline (9) Simple vehicle ownership tax & - & - & - & - & - & (v) & - \\
\hline
\end{tabular}

Note. $\sqrt{ }$ denotes an emissions reduction opportunity exploited by a particular policy; $(\sqrt{ })$ denotes where an opportunity is only partially exploited by the policy; - denotes an opportunity not exploited; and $\times$ denotes where a policy increases rather than reduces emissions. 


\section{Figure 1. Welfare Effects of Externality Taxes with Fiscal Interactions}

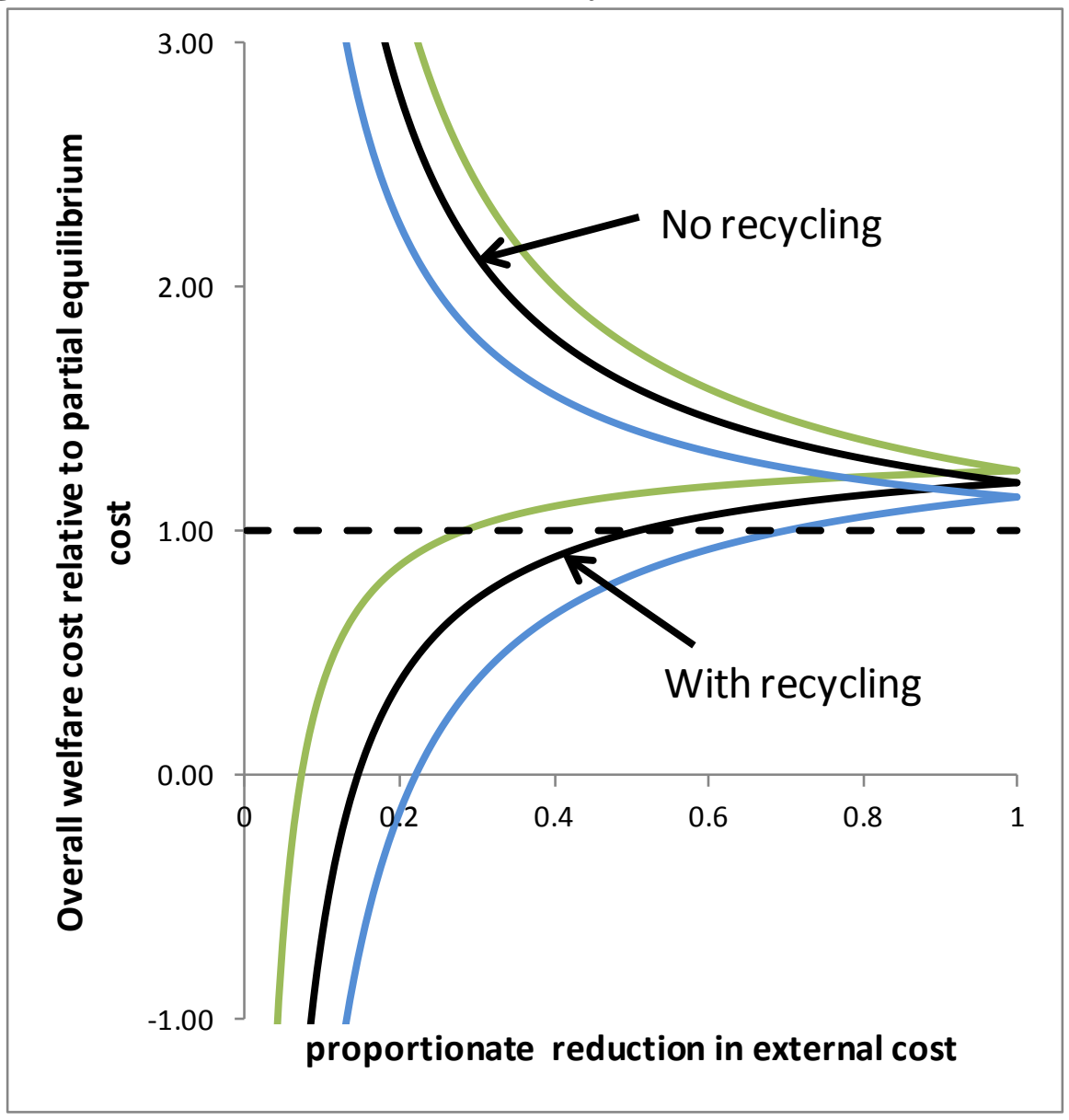

Note. Figure shows rough estimates (based on formulas derived in Parry and Williams 2010) of the welfare costs of taxes to reduce an externality anywhere between 0 and 100 percent, where welfare is expressed relative to the partial equilibrium welfare cost (the Harberger triangle under the marginal abatement cost curve) when fiscal interactions are ignored. The lower set of curves is for a tax when revenues are used to reduce other distorting taxes (with an efficiency cost per extra dollar of revenue raised of 30 cents) and the upper set of curves when revenue recycling effects are foregone. Green, black, and blue curves indicate cases where 80, 60, and 40 percent respectively of the efficiency costs of broader taxes are due to factor market effects distorting the scale of economic activity (as opposed to distortions in the composition of activity due to tax-sheltering behavior). 
Figure 2. Revenue from Environmental taxes as Percent of Total Tax Revenue in OECD Countries, 2010 (or latest available)

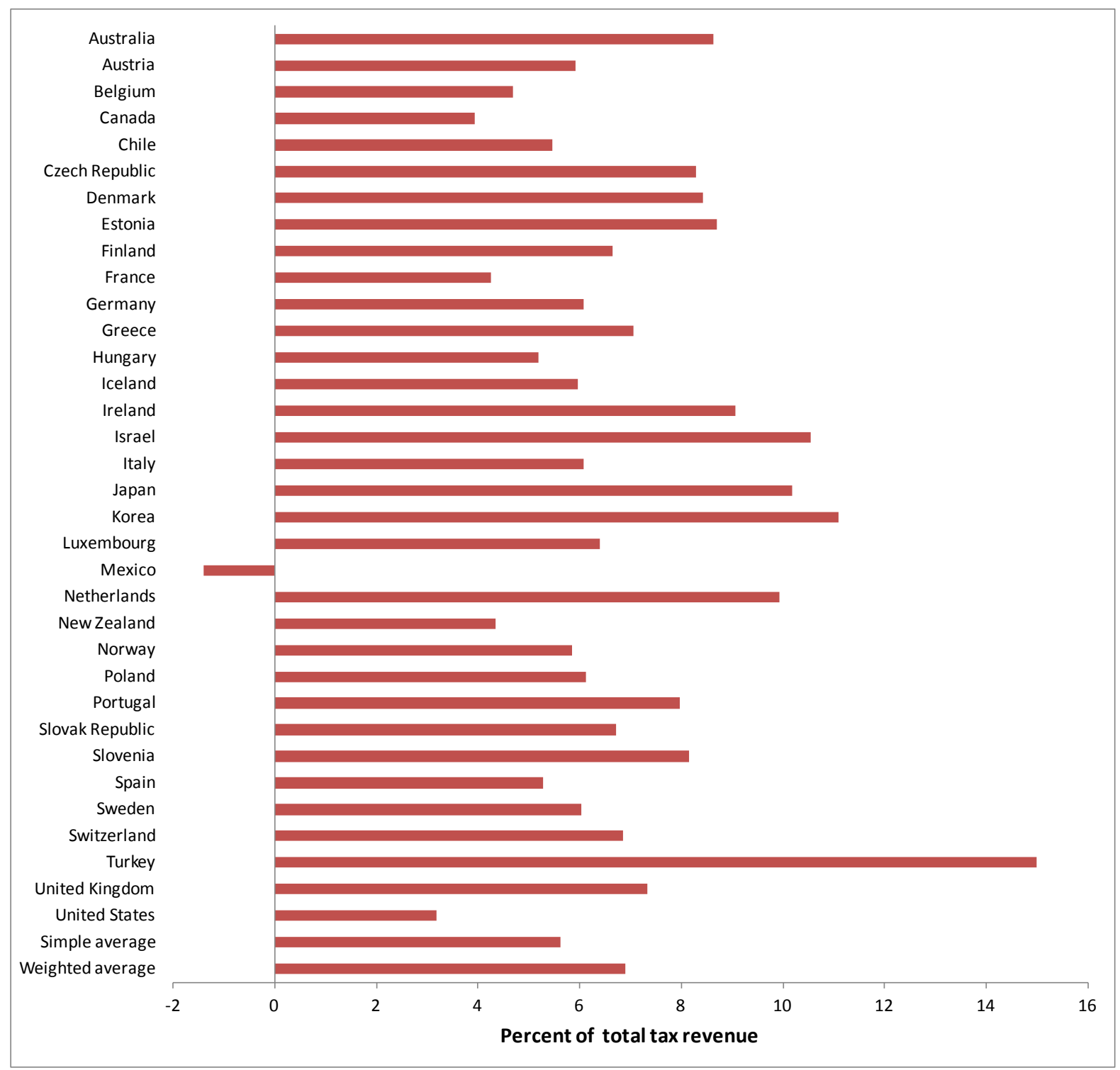

Source. OECD (2013).

Note. Energy subsidies in Mexico have since scaled back since 2010 with energy price liberalization. 
Figure 3. Subsidies for Fossil Fuel Energy by Region and Fuel Type, 2011

(a) Direct Subsidies
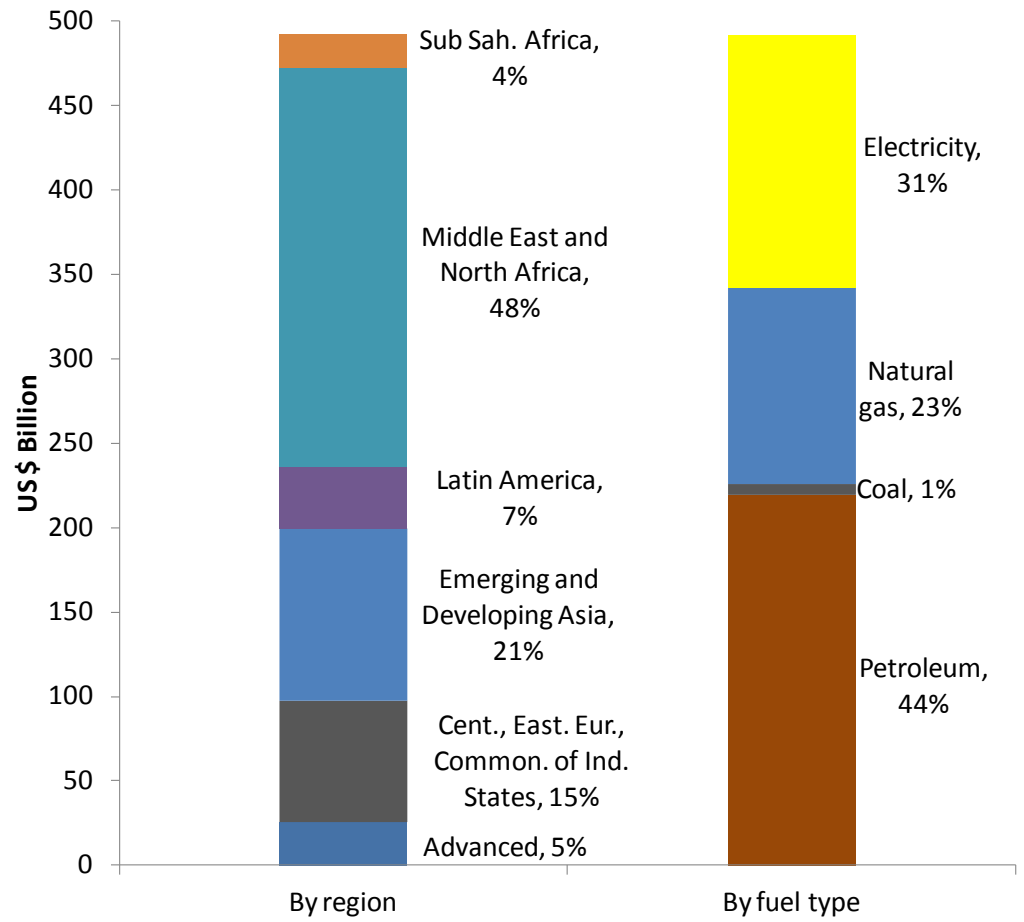

(b) Including Indirect Subsidies from Underpricing of Environmental Damages
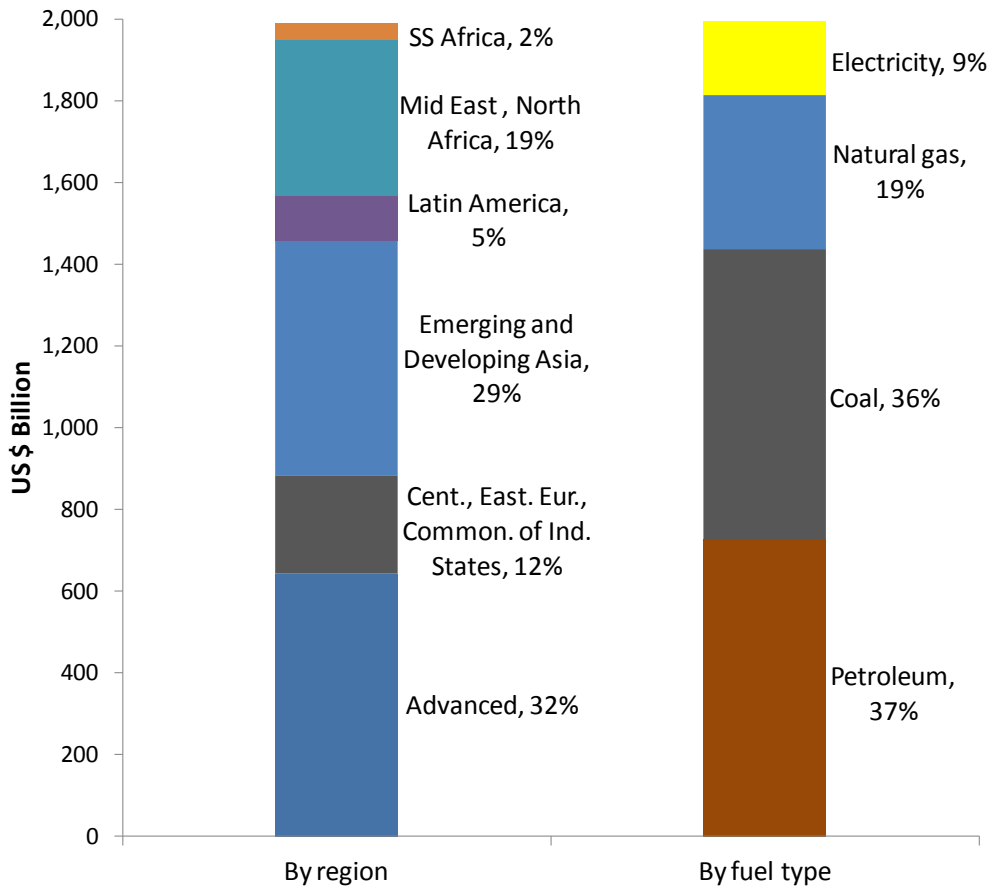

Source. Clements et al. (2013).

Note. Indirect subsidies are based on a crude extrapolation from several country case studies. They also include subsidies from any failure to charge general consumption taxes on household energy products. 
Figure 4. Baseline Mortality Rates for Illnesses whose Prevalence is Increased by Pollution Exposure, by Region, 2010

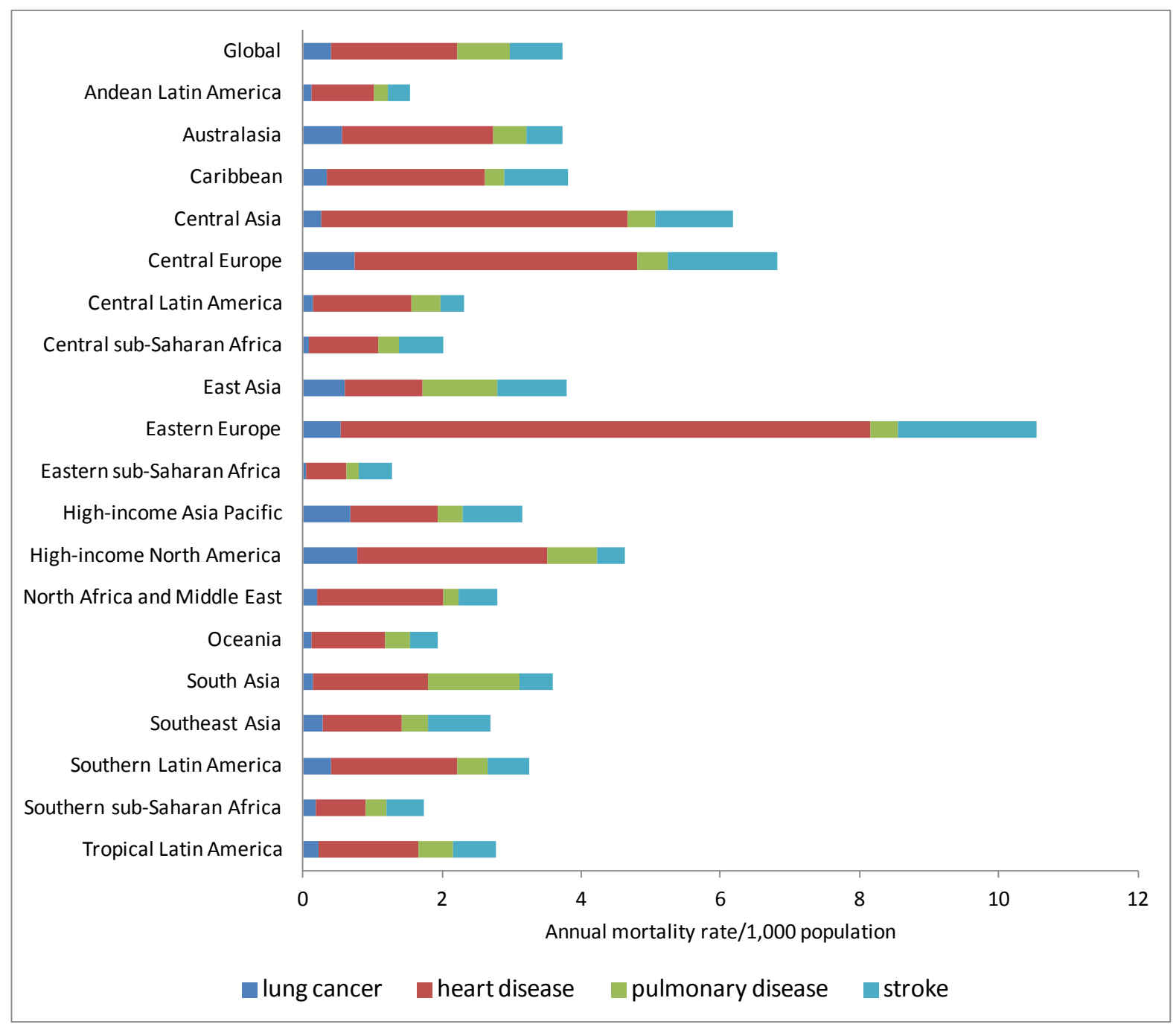

Source. Parry et al. (2014). These estimates were obtained using baseline mortality rates for the four diseases for each region, and by population segment (every five years), from the World Health Organization's Global Burden of Disease (GBD) project. They can be extrapolated to the country level using data on population shares for age segments. 
Figure 5. Damage from Coal Plant $\mathrm{SO}_{2}$ Emissions, Selected Countries, 2010

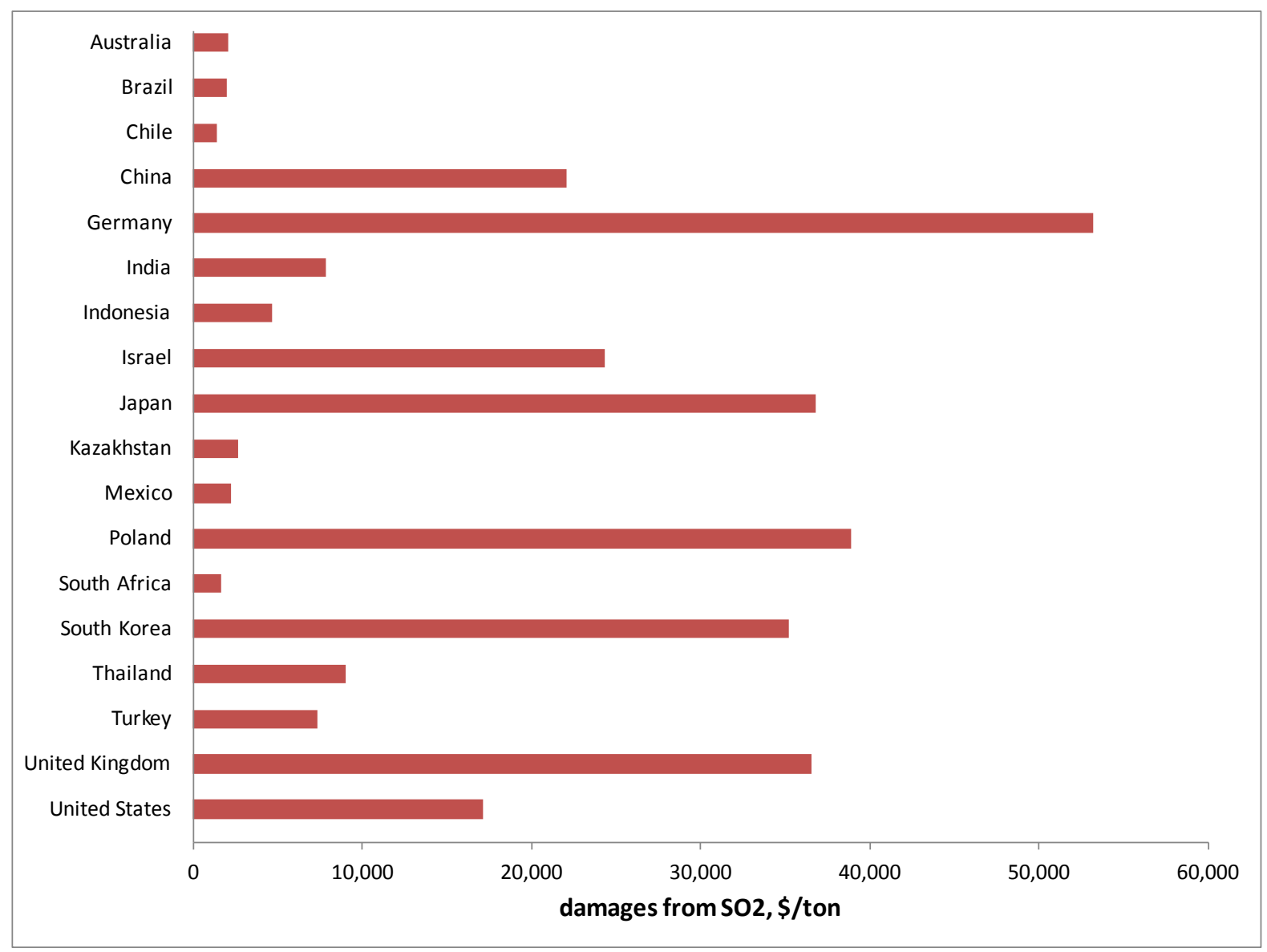

Source. Parry et al. (2014). 
Figure 6. $\mathrm{SO}_{2}$ Emission Rates at Coal Plants, Selected Countries, 2010

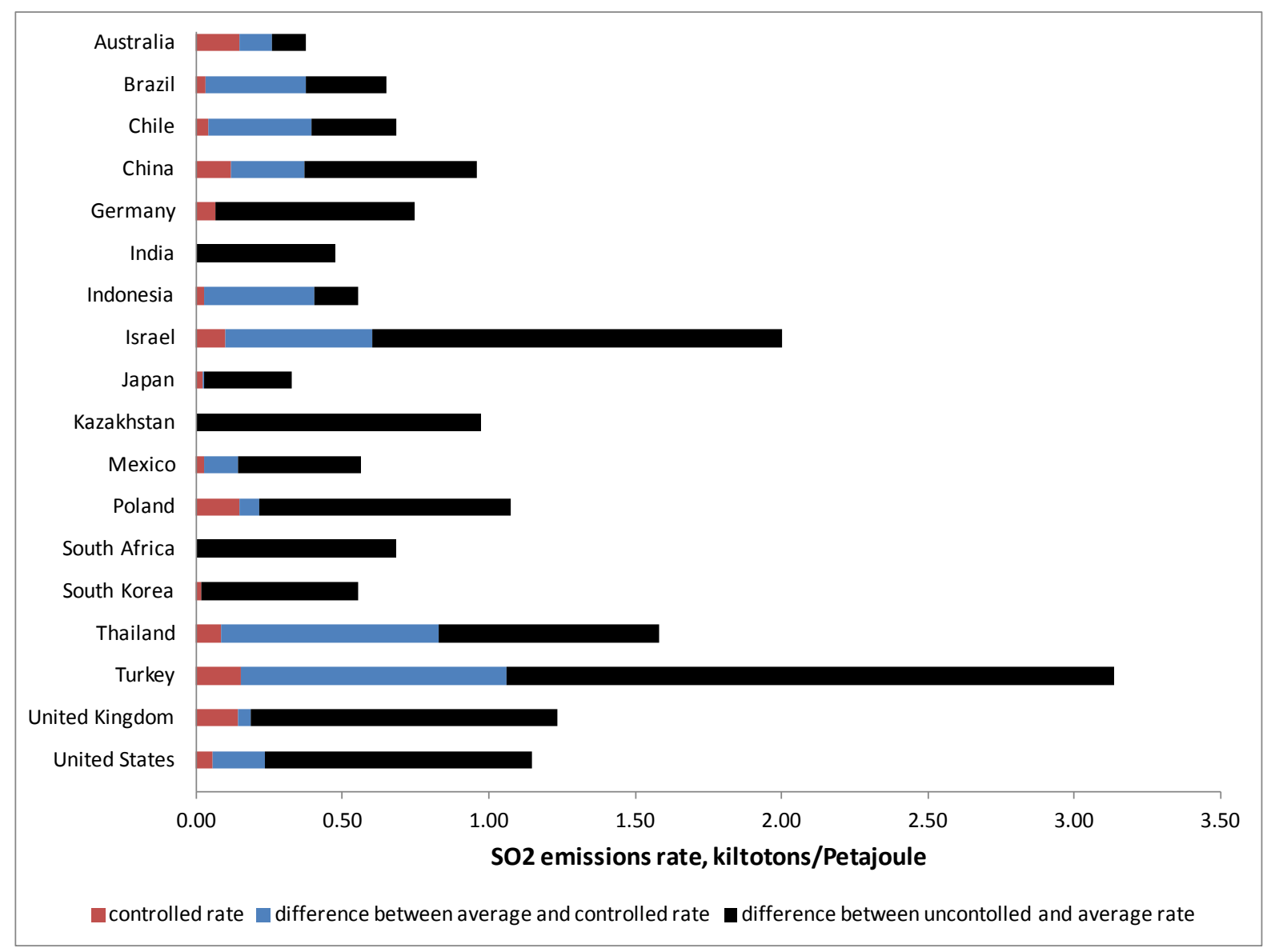

Source. Parry et al. (2014) using calculations from the data compiled by the International Institute for Applied Systems Analysis. 
Figure 7. Corrective Coal Tax Estimates, Selected Countries, 2010

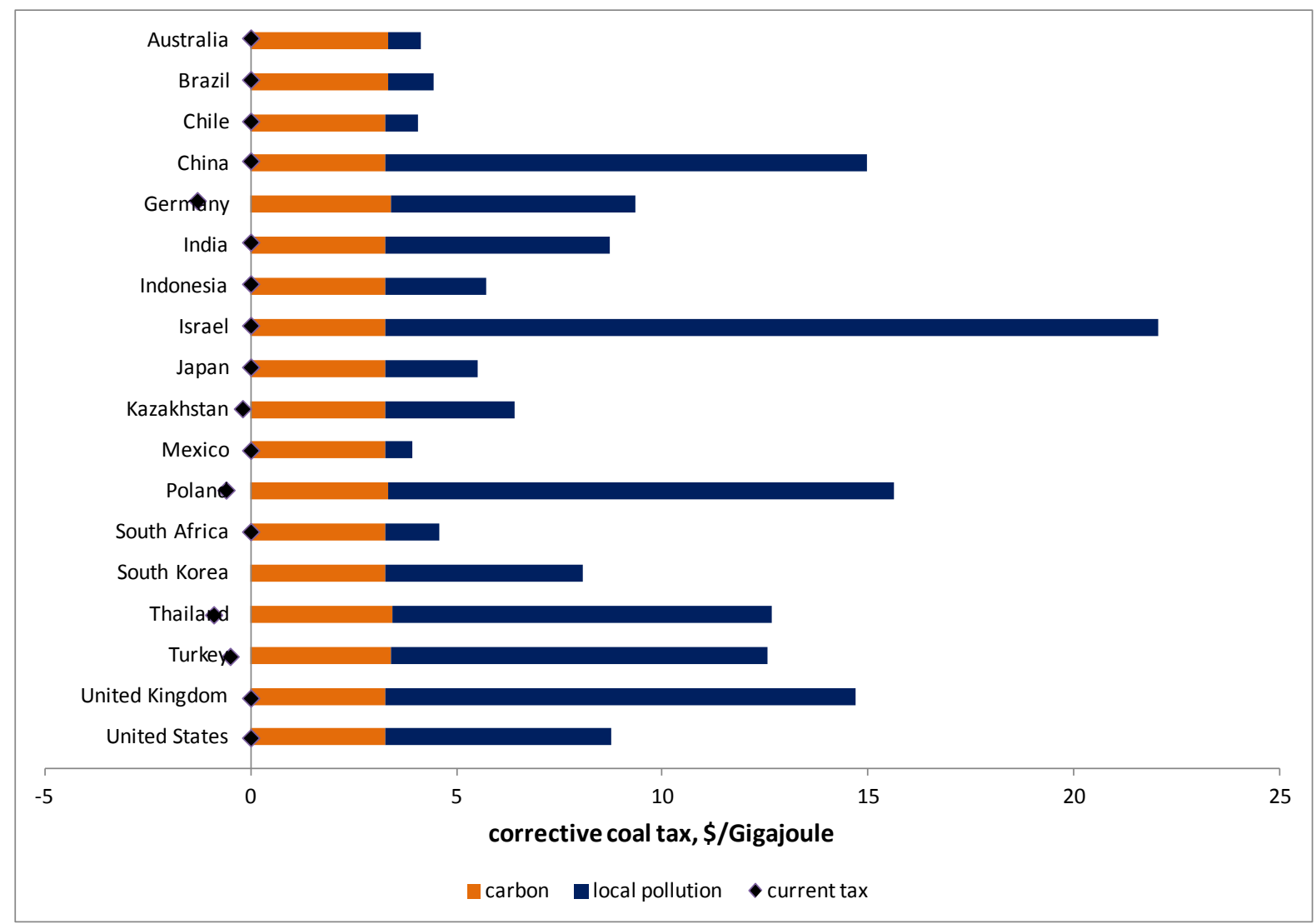

Source. Parry et al. (2014).

Note. Charges for local pollution are based on current emission rates averaged across plants with and without control technologies. 
Figure 8. Corrective Tax Estimates for Power Plant Natural Gas, Selected Countries, 2010

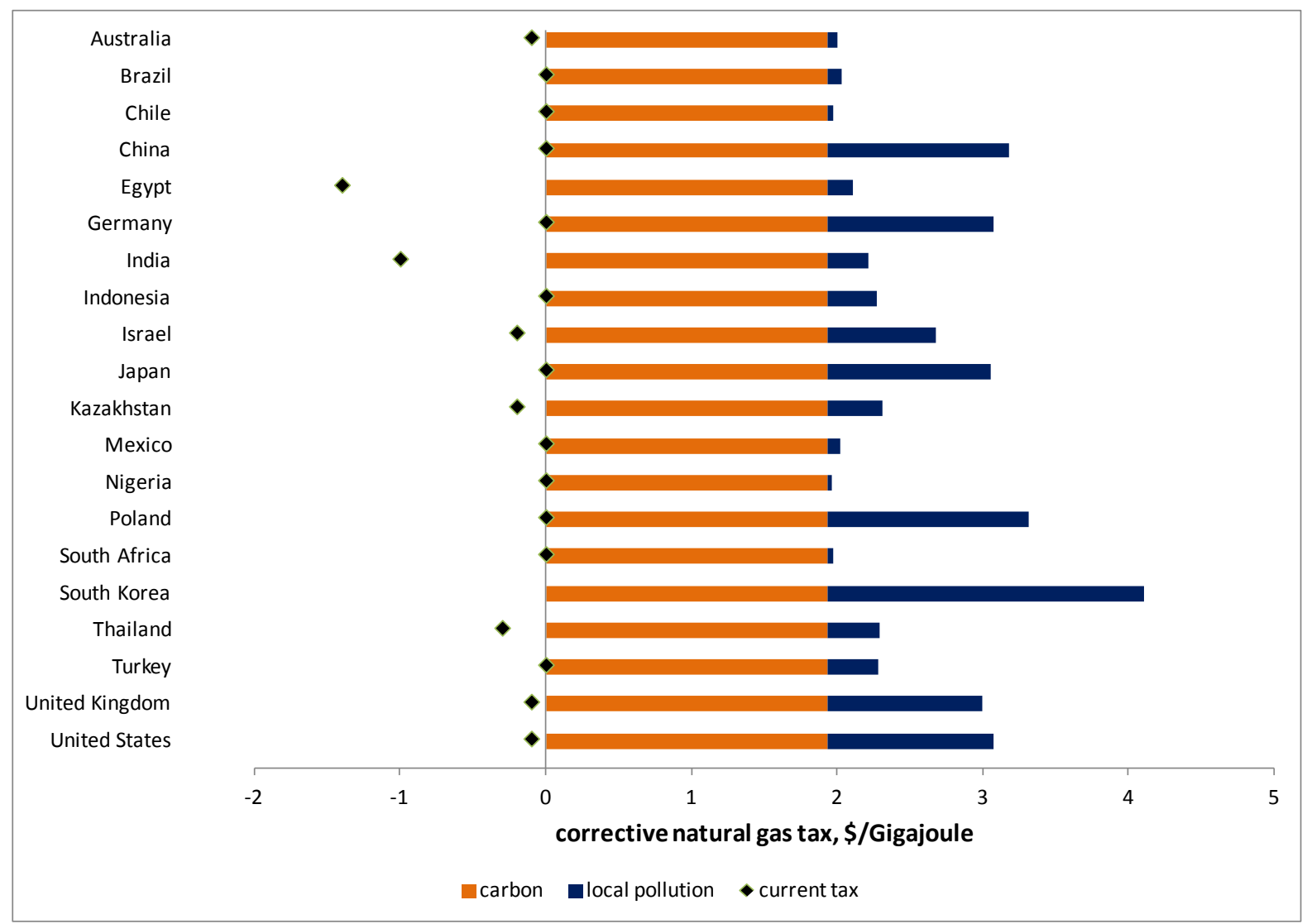

Source. Parry et al. (2014). 
Figure 9. Corrective Gasoline Tax Estimates, Selected Countries, 2010

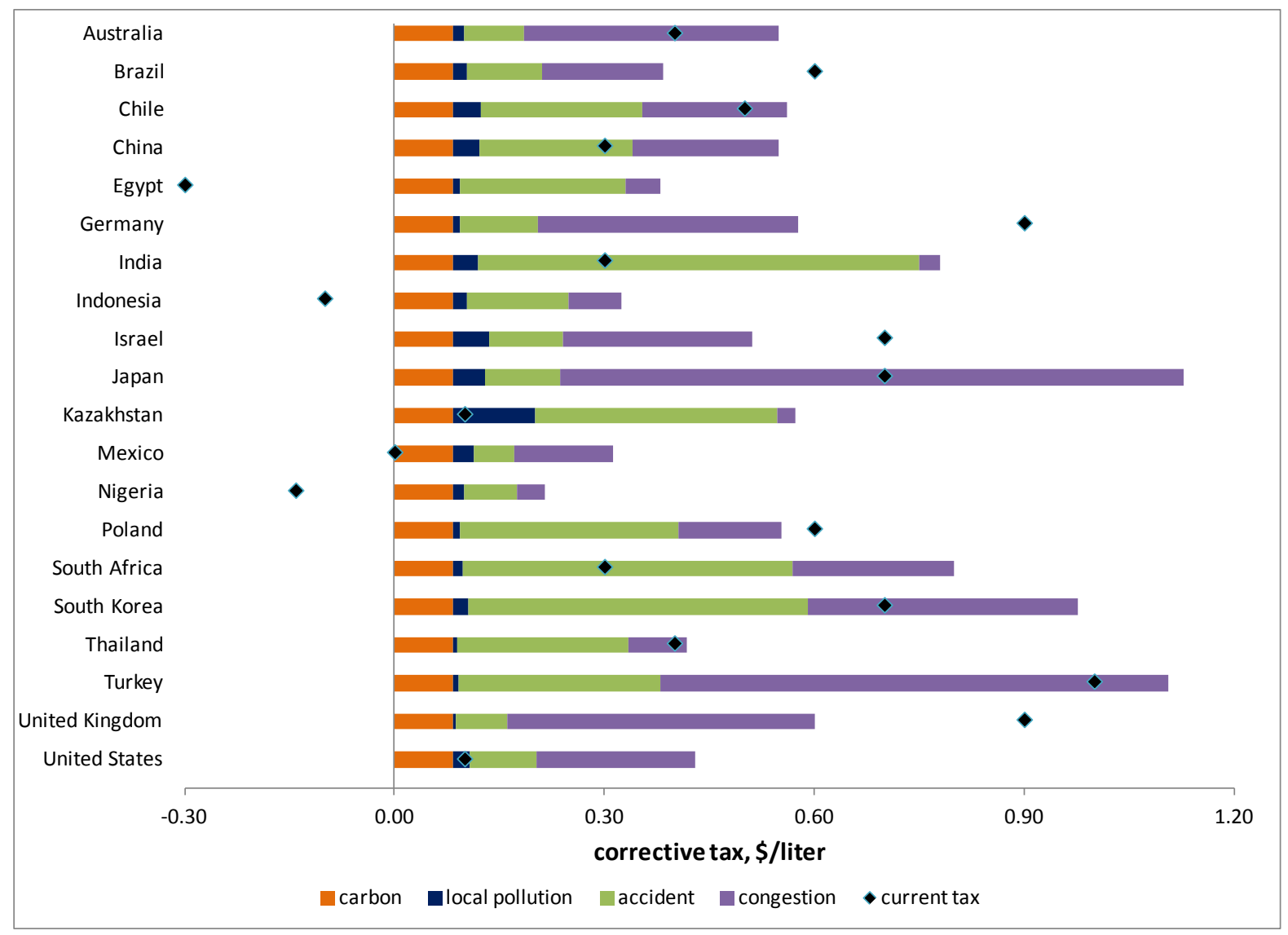

Source. Parry et al. (2014). 
Figure 10. Corrective Diesel Tax Estimates, Selected Countries, 2010

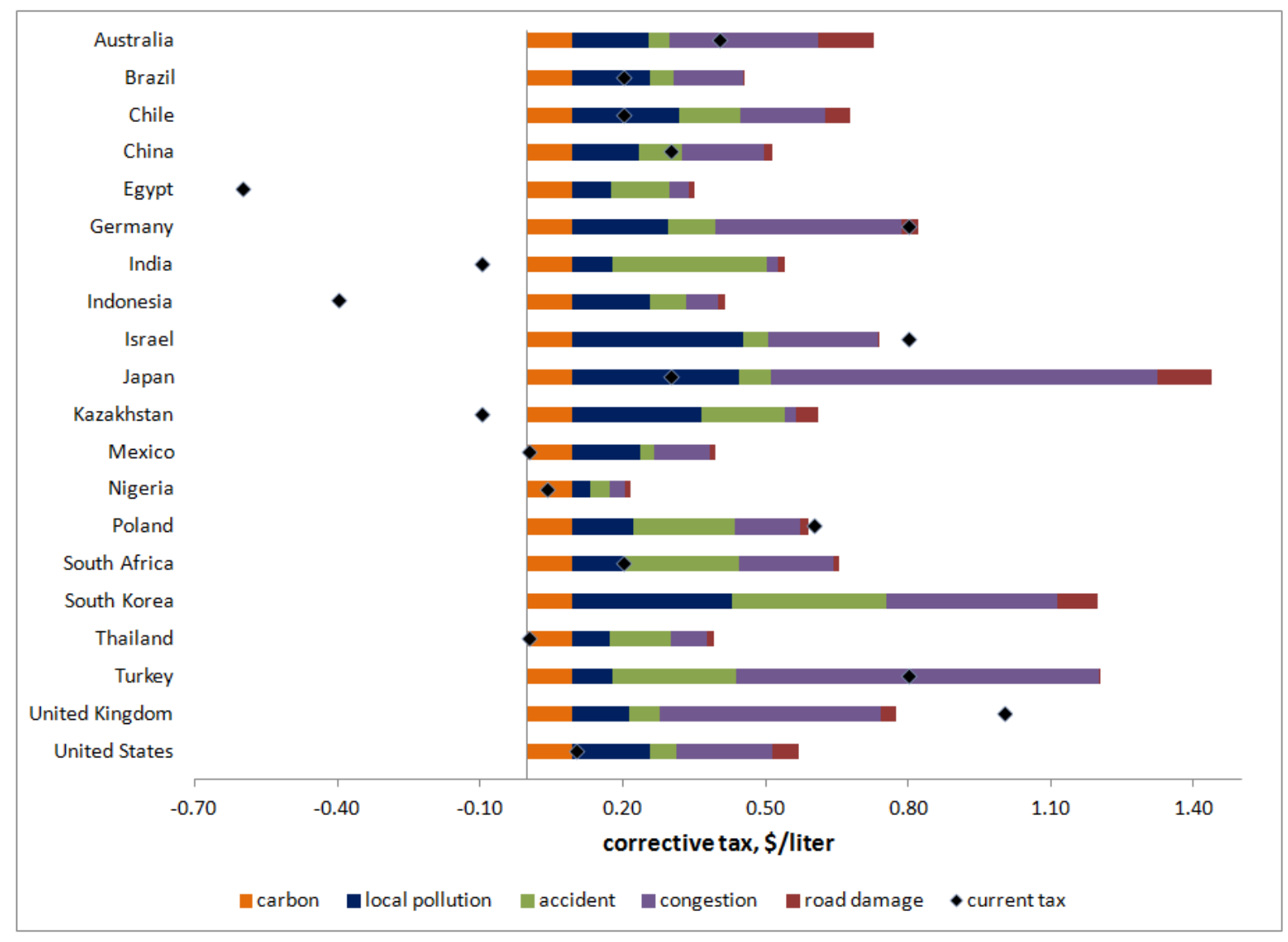

Source. Parry et al. (2014). 
Figure 11. Reduction in Pollution-Related Deaths, Selected Countries, 2010

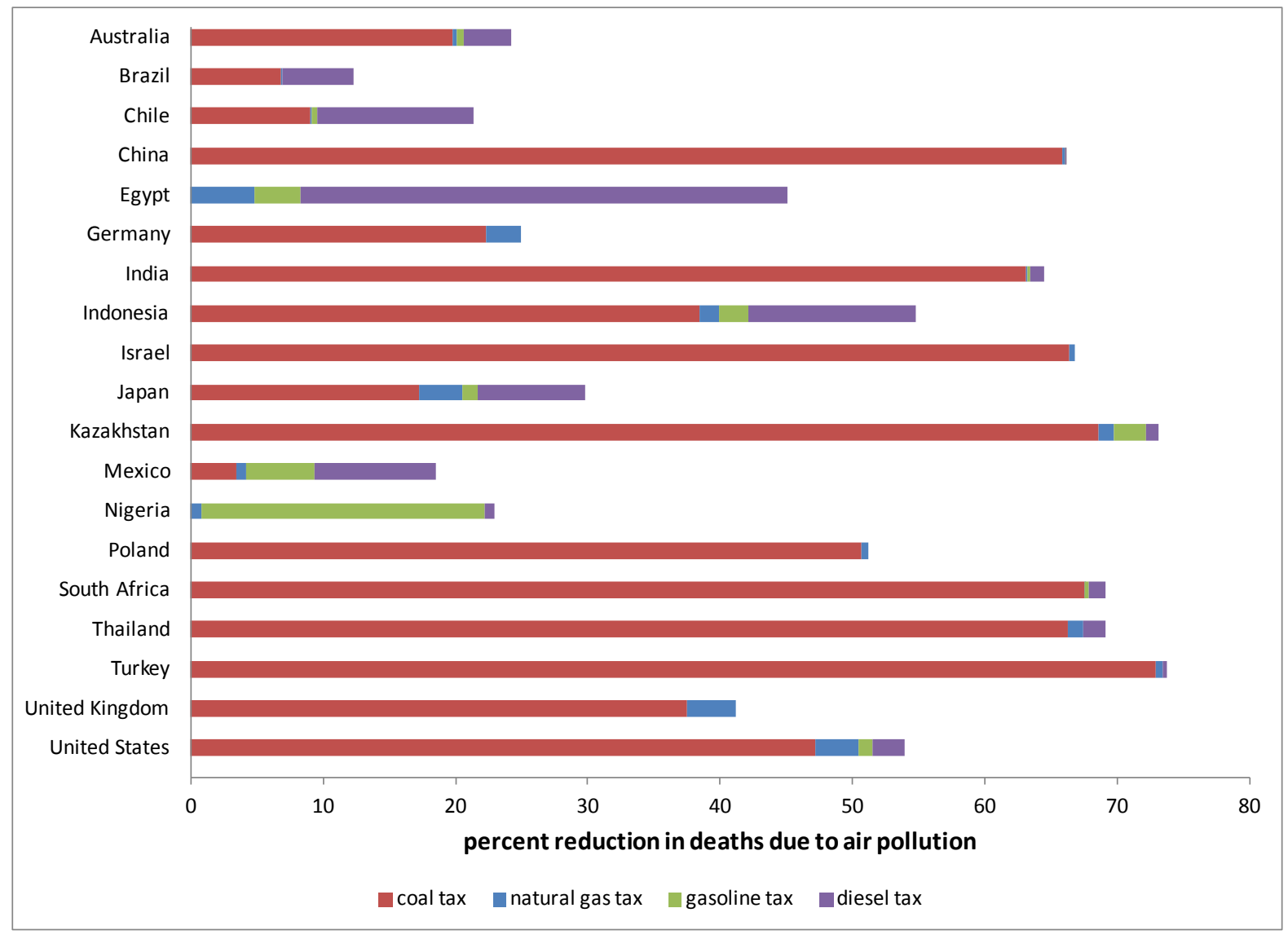

Source. Parry et al. (2014) 
Figure 12. Reduction in Energy-Related $\mathrm{CO}_{2}$ Emissions, Selected Countries, 2010

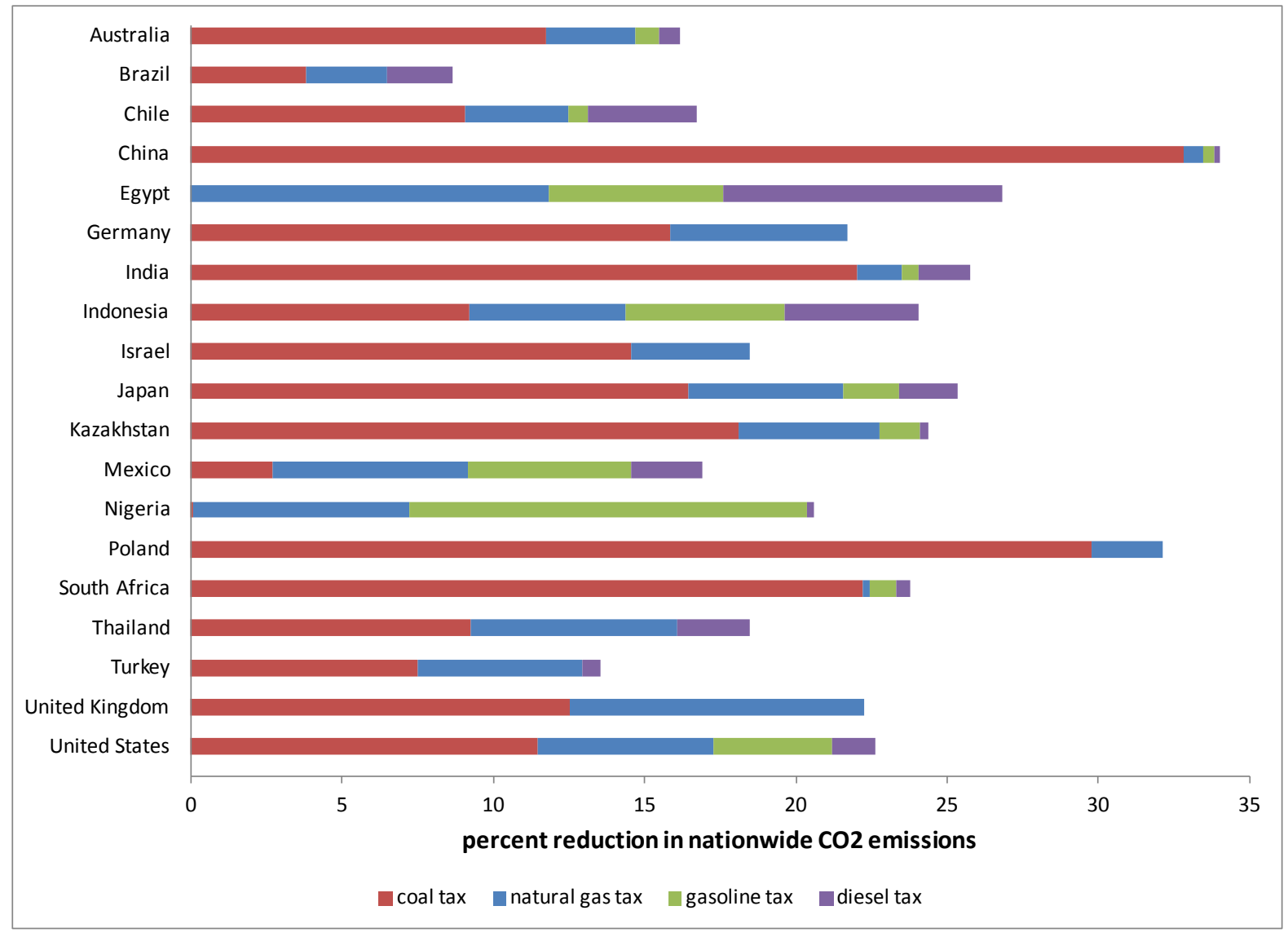

Source. Parry et al. (2014). 
Figure 13. Revenue Gains from Corrective Fuel Taxes, Selected Countries, 2010

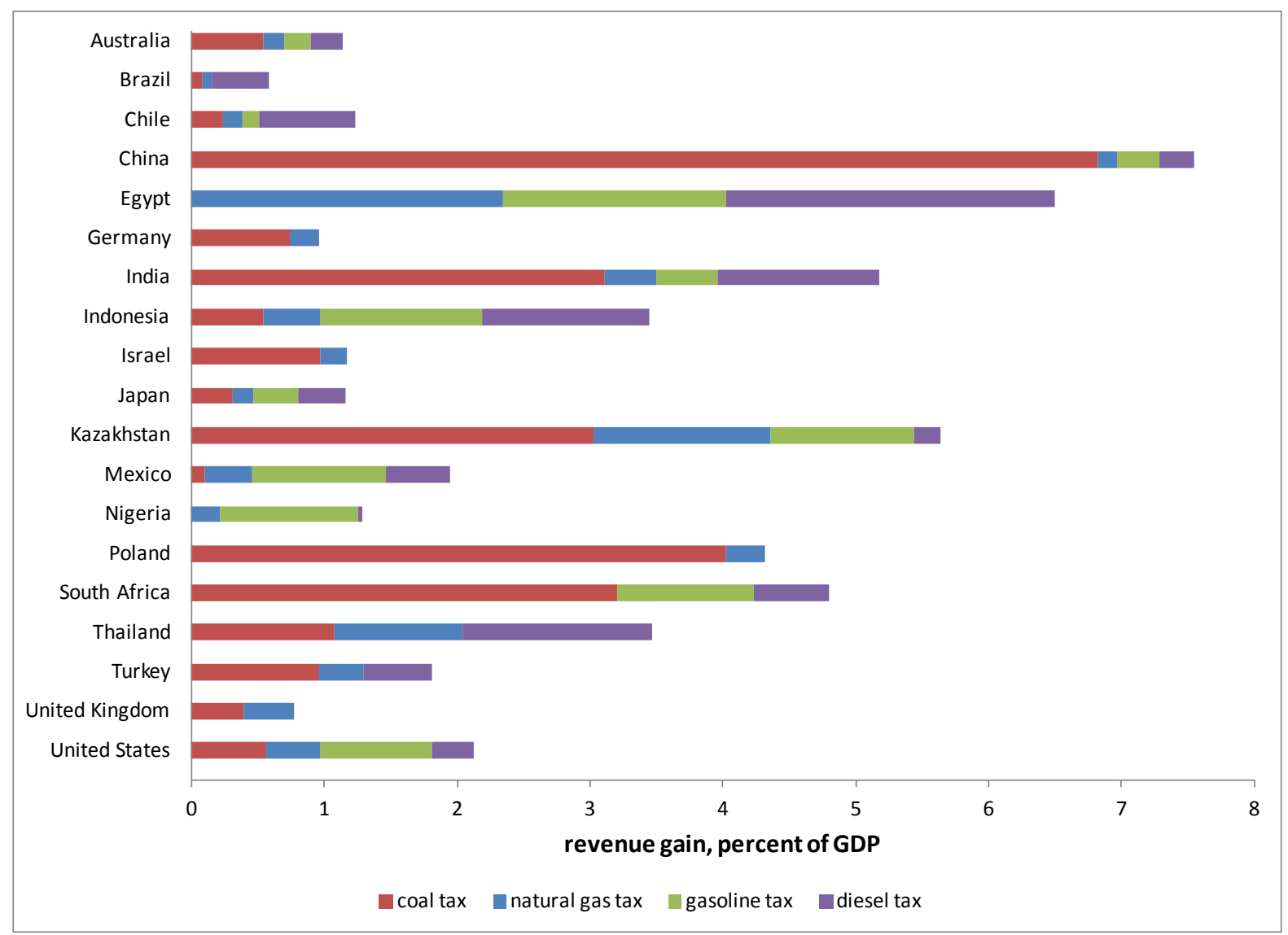

Source. Parry et al. (2014).

Notes. Figure shows revenue gains from corrective fuel taxes relative to revenue from current taxes (which are often zero, and negative in a few cases). In the few cases where current taxes exceed corrective taxes, revenue potential is taken as zero (rather than negative). 